\title{
JOURNAL OF ANIMAL SCIENCE
}

The Premier Journal and Leading Source of New Knowledge and Perspective in Animal Science

\section{RUMINANT NUTRITION SYMPOSIUM: Role of fermentation acid absorption in the regulation of ruminal pH}

J. R. Aschenbach, G. B. Penner, F. Stumpff and G. Gäbel

J ANIM SCI 2011, 89:1092-1107.

doi: 10.2527/jas.2010-3301 originally published online October 15, 2010

The online version of this article, along with updated information and services, is located on the World Wide Web at:

http://www.journalofanimalscience.org/content/89/4/1092 


\title{
RUMINANT NUTRITION SYMPOSIUM: Role of fermentation acid absorption in the regulation of ruminal $\mathrm{pH}^{1,2}$
}

\author{
J. R. Aschenbach, ${ }^{3}$ G. B. Penner, $\dagger$ F. Stumpff,* and G. Gäbel \\ *Institute of Veterinary Physiology, Free University of Berlin, D-14163 Berlin, Germany; \\ $\dagger$ Animal and Poultry Science, University of Saskatchewan, Saskatoon, Saskatchewan, Canada, S7N 5A8; \\ and $\ddagger$ Institute of Veterinary Physiology, University of Leipzig, D-04103 Leipzig, Germany
}

\begin{abstract}
Highly fermentable diets are rapidly converted to organic acids [i.e., short-chain fatty acids (SCFA) and lactic acid] within the rumen. The resulting release of protons can constitute a challenge to the ruminal ecosystem and animal health. Health disturbances, resulting from acidogenic diets, are classified as subacute and acute acidosis based on the degree of ruminal $\mathrm{pH}$ depression. Although increased acid production is a nutritionally desired effect of increased concentrate feeding, the accumulation of protons in the rumen is not. Consequently, mechanisms of proton removal and their quantitative importance are of major interest. Saliva buffers (i.e., bicarbonate, phosphate) have long been identified as important mechanisms for ruminal proton removal. An even larger proportion of protons appears to be removed from the rumen by SCFA absorption across the ruminal epithelium, making efficiency of SCFA absorption a key determinant for the individual susceptibility to subacute ruminal acidosis. Proceeding initially from a model of exclusively diffusional absorption of fermentation acids, several proteindependent mechanisms have been discovered over the last 2 decades. Although the molecular identity of these
\end{abstract}

proteins is mostly uncertain, apical acetate absorption is mediated, to a major degree, via acetate-bicarbonate exchange in addition to another nitrate-sensitive, bicarbonate-independent transport mechanism and lipophilic diffusion. Propionate and butyrate also show partially bicarbonate-dependent transport modes. Basolateral efflux of SCFA and their metabolites has to be mediated primarily by proteins and probably involves the monocarboxylate transporter (MCT1) and anion channels. Although the ruminal epithelium removes a large fraction of protons from the rumen, it also recycles protons to the rumen via apical sodium-proton exchanger, NHE. The latter is stimulated by ruminal SCFA absorption and salivary $\mathrm{Na}^{+}$secretion and protects epithelial integrity. Finally, SCFA absorption also accelerates urea transport into the rumen, which via ammonium recycling, may remove protons from rumen to the blood. Ammonium absorption into the blood is also stimulated by luminal SCFA. It is suggested that the interacting transport processes for SCFA, urea, and ammonia represent evolutionary adaptations of ruminants to actively coordinate energy fermentation, protein assimilation, and $\mathrm{pH}$ regulation in the rumen.

Key words: ammonia, lactic acid, nutrient absorption, ruminal acidosis, ruminal pH, short-chain fatty acid

(C)2011 American Society of Animal Science. All rights reserved.

J. Anim. Sci. 2011. 89:1092-1107 doi:10.2527/jas.2010-3301

\section{INTRODUCTION}

Microbial fermentation of $\mathrm{OM}$ induces shifts in $\mathrm{pH}$ that act on the microbial ecosystem, thus determining the selective growth of certain microbial species, and the types and quantities of fermentation products (Russell and Diez-Gonzalez, 1998; Mouriño et al., 2001; Russell and Rychlik, 2001; Allen et al., 2006). Fermentation of

\footnotetext{
${ }^{1}$ Presented at the Ruminant Nutrition Symposium titled "Acidosis: New Insights Into the Persistent Problem" at the Joint Annual Meeting, July 11 to 15, 2010, Denver, Colorado. The symposium was sponsored, in part, by the West Central Cooperative (Ralston, IA), with publication sponsored by the American Society of Animal Science and the Journal of Animal Science.

${ }^{2}$ The authors appreciate the support of the German Research Foundation (Bonn, Germany; grants Ga 329/5-1, 5-2, 6-1, and 7-1), the Alberta Livestock Industry Development Fund (Edmonton, Alberta, Canada; grant 2008F055R), the Agriculture and Food Council (Nisku, Alberta, Canada), Alberta Milk (Edmonton, Alberta,
}

\footnotetext{
Canada), the Natural Sciences and Engineering Research Council of Canada (Ottawa, Ontario, Canada), and the Margarete Markus Charity (London, UK). Part of the data was acquired with financial assistance from the German Academic Exchange Service (Bonn, Germany) to G. B. Penner. Sincere thanks are expressed to K. A. Beauchemin (Lethbridge, Alberta, Canada) for granting permission to use the data presented in Figure 3.

${ }^{3}$ Corresponding author: aschenbach.joerg@vetmed.fu-berlin.de

Received July 8, 2010.

Accepted October 9, 2010.
} 
carbohydrates releases organic acids that readily dissociate to decrease pH (Allen, 1997; Russell and Rychlik, 2001). In contrast, fermentation of protein or NPN may release excess ammonia, which readily associates with protons to increase pH (Wang and Fung, 1996). When microbial fermentation is utilized for nutrition, either as in-body fermentation (as in the rumen) or as a technology such as silage production, the purpose is mostly to facilitate acid production from carbohydrates while preserving or assimilating protein. Thus, fermentation of nutrients leads to proton release and, thereby, decreases $\mathrm{pH}$. As a consequence, fermentation usually proceeds at $\mathrm{pH}<7$.

The forestomach of ruminants is one of the most refined in-body fermenters utilized for nutrition (Bergman, 1990; Russell and Rychlik, 2001). The pH homeostasis within this fermenter determines not only the biodiversity of the ruminal ecosystem and the nutritional value of the end products, but also animal health because both alkaline and acidic deviations may promote health upsets. Alkaline disturbances of ruminal $\mathrm{pH}$ may occur during excess protein feeding; however, description of ruminal alkalosis is limited to very few reports (Sederevicius and Kantautaité, 1993; Loste et al., 2005). Alternatively, acidic disturbances are a widely acknowledged problem because current intensive production systems rely on intake of large amounts of carbohydrates to meet the energy demand of animals. Because only easily fermentable carbohydrates have sufficient energy density and passage rates to allow for greater energy intakes, intensive feeding strategies are naturally linked to an increased risk of ruminal acidosis (Plaizier et al., 2008; Lechartier and Peyraud, 2010). Fermentation acid absorption plays a key role in counteracting acidosis, and it is evident that a complex system of acid absorption pathways contributes to this outcome. This review aims to analyze the importance of epithelial short-chain fatty acid (SCFA) transport pathways for ruminal $\mathrm{pH}$ regulation in relation to the different components that contribute to proton release, proton buffering, and proton removal in the rumen.

\section{RUMINAL pH PROFILES AND THEIR SIGNIFICANCE}

Ruminal $\mathrm{pH}$ is not only a physicochemical measure with relevance for the fermentation in the rumen, but it is also the central diagnostic criterion to classify ruminal acidosis as a disease that affects more organs than just the rumen (Dirksen, 1970, 1985; Gozho et al., 2005; Dohme et al., 2008; Steele et al., 2009). Clinical presentation of the mild form, called subacute ruminal acidosis (SARA), varies and may include mild transient anorexia, intermittent diarrhea, dehydration, poor body condition, depression, decreased rumen motility, laminitis, unexplained abscesses, and decreased milk production (Dirksen, 1970, 1985; Underwood, 1992; Nordlund and Garrett, 1994; Duffield et al., 2004; Krause and
Oetzel, 2006). Because the disease presentation for SARA is variable and may be evident only because of increased culling rates, the presence of an abnormal ruminal $\mathrm{pH}$ is used as the final decisive criterion for diagnosis (Duffield et al., 2004; Krause and Oetzel, 2006). It may appear peculiar that a single measurement item from a sequestrated "transcellular" compartment (i.e., ruminal $\mathrm{pH}$ ) can satisfactorily serve to diagnose a complex internal disease. Indeed, the relationship between ruminal $\mathrm{pH}$ and a given clinical sign (e.g., going off feed) is certainly not linear (Uhart and Carroll, 1967), which supports the view that ruminal $\mathrm{pH}$ is a crucial risk factor rather than a unique diagnostic criterion for ruminal acidosis. Nonetheless, if ruminal $\mathrm{pH}$ is the final decisive criterion to diagnose and classify a multiorgan disease, it should be mandatory to measure it as representatively as possible and to standardize and improve the diagnostic interpretation.

The 2 major challenges for collecting and comparing ruminal $\mathrm{pH}$ data are that ruminal $\mathrm{pH}$ is not homogeneously distributed throughout the rumen (Duffield et al., 2004; Zebeli et al., 2008b) and that different sampling techniques will produce different results (Nordlund and Garrett, 1994; Duffield et al., 2004). The standardized sampling site for ruminal $\mathrm{pH}$ is the (cranial-)ventral ruminal sac because this is the place where most mixing of ruminal contents occurs (Duffield et al., 2004). The ventral ruminal sac thus provides the most integrated information on the $\mathrm{pH}$ status of the whole rumen (as long as motility is intact), and the term "ruminal $\mathrm{pH}$ " is often used synonymously for "ventral ruminal $\mathrm{pH}$ ". Unfortunately, $\mathrm{pH}$ measurements in ruminal fluid samples from the ventral ruminal sac recovered by orogastric tube or ruminocentesis show only poor to moderate correlation to the ventral ruminal pH measured in situ (Duffield et al., 2004). In situ measurement of ruminal $\mathrm{pH}$ is thus necessary if results with greater precision are desired. Over the last several years, great efforts have been made to accurately measure ventral ruminal $\mathrm{pH}$ in situ over time by indwelling systems, which has already led to a greatly improved understanding of ruminal $\mathrm{pH}$ dynamics. Indwelling systems are available for tethered (Dado and Allen, 1993) and nontethered, ruminally cannulated cattle (Graf et al., 2005; Penner et al., 2006; AlZahal et al., 2007), as well as for noncannulated small ruminants (Penner et al., 2009b). The great advantage of these systems is a good time resolution over several days or weeks when investigating the relationship between meal size, diet fermentability, eating behavior, and ruminal pH (Maekawa et al., 2002; Krause and Combs, 2003; Penner et al., 2009b). Because the ventral indwelling sensors reside close to the ruminal epithelium, the data collected should have greater predictive value for the $\mathrm{pH}$ environment above the epithelium, even though the immediate surface microenvironment of the epithelium is slightly more alkaline when urea hydrolysis (Cheng and Wallace, 1979) and epithelial $\mathrm{HCO}_{3}{ }^{-}$secretion (Leonhard-Marek et al., 2006) are active. 
Whereas the time resolution of ruminal $\mathrm{pH}$ measurement has greatly improved, the site resolution or the time $\times$ site resolution is still a matter of concern. $\mathrm{Ru}-$ men stratification can cause extensive $\mathrm{pH}$ gradients within the rumen. The $\mathrm{pH}$ values in the rumen mat (Zebeli et al., 2008b; Storm and Kristensen, 2010) and central portion of the rumen (Duffield et al., 2004) have been reported to be 0.16 to 0.73 units less compared with those from the ventral sac. The $\mathrm{pH}$ conditions under which the major part of fermentation occurs should, thus, be slightly more acidic than predicted from ventral ruminal $\mathrm{pH}$. Additional measurements in the ruminal mat have, thus, a potential to improve the precision when predicting fiber digestibility, fermentation patterns, and health consequences of feeding regimens based on easily fermentable carbohydrates. Sensors for continuous indwelling measurement in the dorsal ruminal area have just become commercially available (Laporte-Uribe et al., 2010).

With regard to ruminal acidosis, the definition of tolerable $\mathrm{pH}$ thresholds has to take into account the vulnerability of both the ruminal ecosystem and the ruminal epithelium. It is well established that starch feeding and prolonged reductions in ruminal $\mathrm{pH}$ less than 6.0 greatly facilitate the growth of amylolytic bacteria (Mackie and Gilchrist, 1979) while cellulolytic bacteria and NDF digestibility are concurrently inhibited (Russell and Wilson, 1996; Krajcarski-Hunt et al., 2002). Additionally, a marked proliferation of lactate-utilizing bacteria occurs at pH 5.8 (Mackie and Gilchrist, 1979). These events are linked to profound shifts in fermentation pattern with increasing proportions of propionate and sometimes butyrate (Bannink et al., 2008). Based on changes in microbial composition and activity, a first $\mathrm{pH}$ threshold around 5.8 is justified. This threshold coincides with the first vulnerability threshold of the ruminal epithelium because early inflammatory responses may occur when ruminal $\mathrm{pH}$ is $<5.6$ for $>1 \mathrm{~h}$ (Gozho et al., 2005). A second threshold exists as $\mathrm{pH}$ decreases further toward 5.0. Ruminal protozoa die and fermentation shifts to release large amounts of lactic acid (Dirksen, 1970; Stone, 2004; Lettat et al., 2010), which appears to be mainly attributable to an overgrowth by Streptococcus bovis (Hungate et al., 1952; Dirksen, 1970; Gill et al., 2000). This second threshold also coincides with a second vulnerability threshold of the ruminal epithelium, where an immediate and persistent compromise of transport and barrier function occurs at approximately pH 5.1 (Gaebel et al., 1987; Gaebel and Martens, 1988; Aschenbach and Gäbel, 2000).

When applying the quoted $\mathrm{pH}$ values, it needs to be considered that every biological system is dynamic by nature with no clear-cut thresholds. Additionally, the $\mathrm{pH}$ of the bulk solution (e.g., ventral ruminal $\mathrm{pH}$ ) is not completely identical to the $\mathrm{pH}$ directly at the epithelial surface (Leonhard-Marek et al., 2006), and ruminal motility may greatly affect $\mathrm{pH}$ gradients from the lumen to the epithelium. As a consequence, decreasing of ruminal $\mathrm{pH}$ into the range defined for SARA does not always cause inflammation (Khafipour et al., 2009) or result in decreased productive performance (Oba and Allen, 2003a,b). Although we do not currently understand all the different factors that can modify the effect of low $\mathrm{pH}$ on the ruminal ecosystem and the ruminal epithelium, it has been specifically suggested that the intake of ruminally fermentable OM may be an important accessory factor and a useful additional criterion for the diagnosis of ruminal acidosis (Penner et al., 2009c).

The dynamic nature of the effects of low $\mathrm{pH}$ on the ruminal ecosystem and the ruminal epithelium have led to the use of different thresholds for acidosis classification among research groups, with thresholds ranging between 5.5 and 5.8 for SARA (Kleen et al., 2003; Krause and Oetzel, 2006; Penner et al., 2007) and 5.0 and 5.2 for acute ruminal acidosis (Dirksen, 1985; Nocek, 1997; Penner et al., 2007). The smaller threshold values (5.5. and 5.0, respectively) appear to be appropriate when taking single measurements or nadir $\mathrm{pH}$ as the decision criterion for subacute and acute acidosis, respectively (Dirksen, 1985; Kleen et al., 2003). The greater values (5.8 and 5.2, respectively) appear more appropriate when making decisions based on the duration or area $(\mathrm{pH} \times$ duration) spent below these thresholds (i.e., when considering that only prolonged or repeated periods below the thresholds may lead to subacute or acute health disturbances; Gozho et al., 2005; Penner et al., 2007).

Although decreases in ruminal $\mathrm{pH}$ may originate from the intake of acidic feed (e.g., silage), the intraruminal production of fermentation acids from concentrate has by far the largest effect on ruminal $\mathrm{pH}$ (Lechartier and Peyraud, 2010; see next 2 sections). As intake and fermentation vary, ruminal $\mathrm{pH}$ also varies markedly throughout the day and may differ substantially within an animal for consecutive days (Figure 1). Thus, only continuous measurement of ruminal $\mathrm{pH}$ over an extended period can serve to adequately evaluate ruminal acid-base balance. Variation within a day is largely affected by the consumption of meals, with $\mathrm{pH}$ decreasing after a meal and slowly recovering until the next meal (Allen, 1997). Variation in the $\mathrm{pH}$ response demonstrates that, at times, the rate of acid production exceeds the rate of acid removal or proton buffering. Soluble carbohydrates and starch are most effective in decreasing ruminal $\mathrm{pH}$ rapidly, whereas increasing the amount of physically effective fiber in the ration is the most efficient nutritional measure to alleviate the $\mathrm{pH}$ decline after a meal (Allen, 1997; Zebeli et al., 2008a). The reason for variation among days has not been addressed specifically but is most likely related to DMI; however, DMI is not exclusively related to ruminal $\mathrm{pH}$, at least not in the long term (Penner et al., 2007; Figure 2). Variation among animals in their $\mathrm{pH}$ response to a common diet is also prevalent and has received considerable attention in recent years (Brown et al., 2000; Bevans et al., 2005; Penner et al., 2009b,c). The 


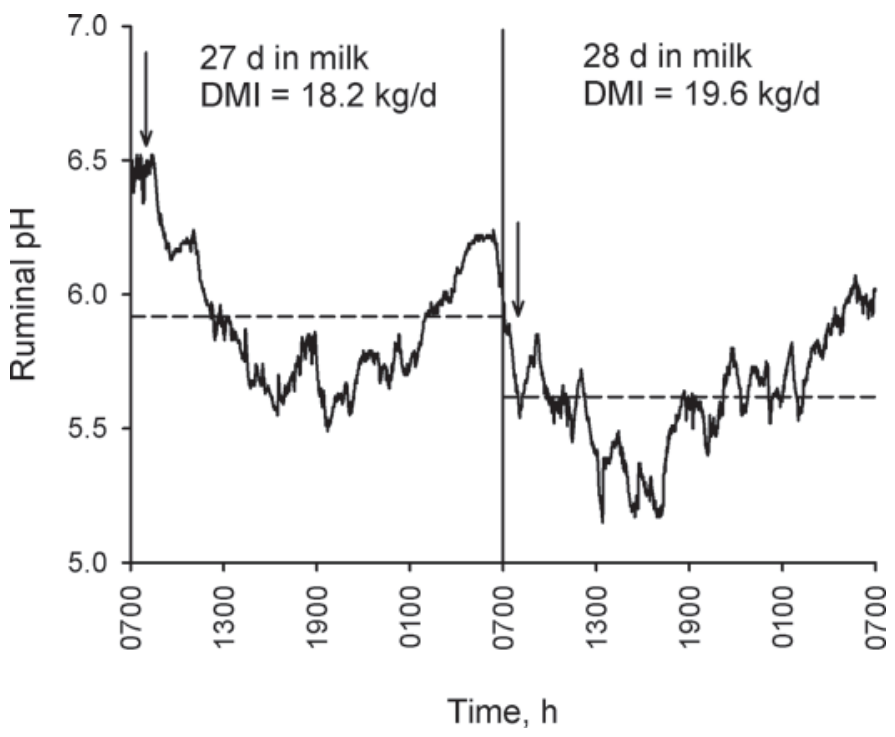

Figure 1. Variation in the ruminal $\mathrm{pH}$ response for 1 cow on 2 consecutive days ( 27 and $28 \mathrm{~d}$ in milk). The solid line indicates the ruminal $\mathrm{pH}$ value (data collected every $30 \mathrm{~s}$ and averaged over 1-min intervals), the dashed line indicates mean ruminal $\mathrm{pH}$ for each individual day (5.92 for $\mathrm{d} 27$ and 5.62 for $\mathrm{d} 28$ ), and the arrows depict the time of feeding $(0800 \mathrm{~h})$. The areas under the curve for $\mathrm{pH}<5.8(\mathrm{pH} \times$ h/d) were 1.22 and 4.88 for $\mathrm{d} 27$ and 28, respectively. Excerpt of data from Penner and Oba (2009).

latter appears to be highly correlated to differences in fermentation acid absorption (Penner et al., 2009b), as will be elaborated in subsequent sections.

\section{ESTIMATES OF RUMINAL ACID PRODUCTION}

The nutritional relevance of acid production in the rumen was first postulated by Zuntz (1879). Since then, it has been the focus of many studies, with findings demonstrating that absorption of SCFA contributes substantially to the total ME supply for ruminants (as summarized by Bergman, 1990). The major fermentation acids are the SCFA, acetic, propionic, and butyric acids, with molar proportions of each in the ruminal fluid ranging from 45 to $70 \%, 15$ to $40 \%$, and 5 to $20 \%$, respectively (Bergman, 1990; Kristensen et al., 1996; Penner et al., 2009c; Udén, 2010). The 3 SCFA generally represent $>95 \%$ of all fermentation acids, with a cumulative concentration of 60 to $150 \mathrm{mmol} / \mathrm{L}$ in ruminal fluid (Bergman, 1990). It has been suggested that the molar proportions of individual SCFA in the ruminal fluid are somehow indicative of their fractional production rates (Udén, 2010). However, most studies allow no or only limited conclusions on the production rates of individual SCFA.

Approaches to quantify fermentation acid production are mainly based on isotopic tracer techniques (Martin et al., 2001; Sutton et al., 2003) or the measurement of the portal appearance of SCFA and metabolites (Kristensen, 2005; Loncke et al., 2009). Although both these methods may be used to quantify acid production, they differ in the measurement outcome: measurement of to- tal or net acid production, respectively. It should be acknowledged that both methods have major limitations. Isotopic tracer techniques are susceptible to carbon sequestration by ruminal microbes (Kristensen, 2001) and microbial carbon interconversion of SCFA as an error source (Sutton et al., 2003), whereas portal appearance studies systematically lead to an underestimation of produced acids due to differences between the rate of acid production and acid removal, as well as SCFA metabolism by the pregastric epithelia (Kristensen, 2005). Nevertheless, quantifying acid production in the rumen is of critical importance for predicting the nutrient supply and identifying the potential for $\mathrm{pH}$ depression.

It is clear that dietary composition and level of intake, particularly the intake of ruminally fermentable OM, affect total SCFA production and the molar proportions of individual SCFA (Bannink et al., 2008; Loncke et al., 2009). In fact, Loncke et al. (2009), based on a meta-analysis of net portal appearance data, predicted that a $5.93 \mathrm{mmol} /(\mathrm{d} \cdot \mathrm{kg}$ of $\mathrm{BW})$ increase in SCFA production would occur for every $1 \mathrm{~g} /(\mathrm{d} \cdot \mathrm{kg}$ of $\mathrm{BW}$ ) increase in ruminally fermentable $\mathrm{OM}$ intake. Correspondingly, increasing the ruminally fermentable NDF:ruminally fermentable OM ratio increased the proportion of acetate and propionate but decreased butyrate. The models proposed by Loncke et al. (2009) covered a wide range of dietary conditions but did not include data from animals fed high-concentrate diets, such as feedlot cattle, or animals with a greater level of feed intake, such as dairy cattle in early lactation. This area requires further investigation as the amount of acid production and type of acids produced may shift (i.e., increased lactic acid production; Owens et al., 1998). The quantity of acid produced may also be affected by the extent of $\mathrm{OM}$ fermentation in the rumen and the efficiency of microbial fermentation (i.e., yield/ $\mathrm{kg}$ of ruminally fermented OM; Allen, 1997). Based on

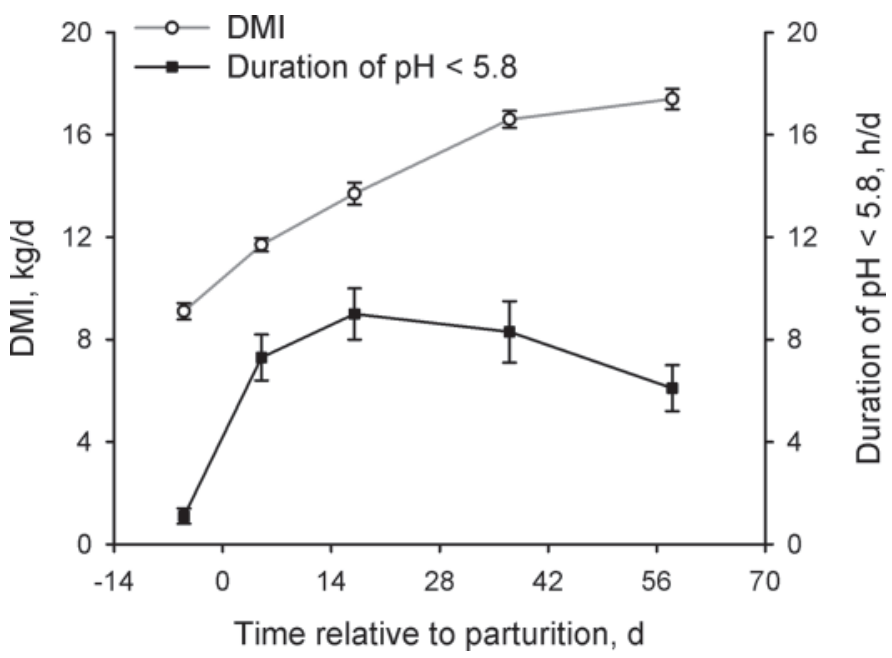

Figure 2. Changes in DMI (linear, $P<0.001$; quadratic, $P=$ 0.042 ) and duration that ruminal $\mathrm{pH}$ was $<5.8$ (quadratic, $P<0.001$ ) during the periparturient period in primiparous Holstein cows $(\mathrm{n}=$ 14). Data derived from Penner et al. (2007). 
the isotopic dilution method, rates of SCFA production in sheep fed at high and low intake (90 and 45\% ad libitum intake, respectively) ranged between 14.8 and $8.8 \mathrm{~mol} / \mathrm{d}$ (Martin et al., 2001) and for dairy cows fed diets with concentrate-to-hay ratios of 60:40 and 90:10 at moderate intake $(\sim 13 \mathrm{~kg} / \mathrm{d}$ of DMI), total SCFA production rates ranged between 79.8 and $90.0 \mathrm{~mol} / \mathrm{d}$ (Sutton et al., 2003).

At physiological ranges of $\mathrm{pH}$, production of $1 \mathrm{~mol}$ of SFCA is initially associated with the release of 1 mol of $\mathrm{H}^{+}$(see subsequent discussion). The ratio may be somewhat less in forages based on their greater dietary cation-anion difference, because fermentation of already buffered organic anions in the plant cytosol will not release additional $\mathrm{H}^{+}$. However, even on pasturebased diets, a negative within-study correlation has been found between the concentration of SCFA in the ruminal fluid and ruminal $\mathrm{pH}\left(\mathrm{r}^{2}=0.80\right.$; Kolver and de Veth, 2002). Across studies with different diets, however, this relationship was rather weak $\left(\mathrm{r}^{2}=0.13\right.$; Allen, 1997). That the concentration of SCFA explains only a certain proportion of variation in ruminal $\mathrm{pH}$ is explained by different removal of dissociated $\mathrm{H}^{+}$from the rumen through neutralization, absorption, and clearance (Allen, 1997).

Although each individual SCFA can dissociate to yield $1 \mathrm{H}^{+}$, the type of SCFA produced through fermentation may result in a different quantity of acid produced per unit of hexose fermented. For example, fermentation of $1 \mathrm{~mol}$ of glucose can result in $2 \mathrm{~mol}$ of acetic, $2 \mathrm{~mol}$ of propionic, or $1 \mathrm{~mol}$ of butyric acid (Baldwin, 1995; Bannink et al., 2006). Thus, fermentation promoting butyric acid production may produce less acid compared with fermentation promoting acetic and propionic acids. Although substrate fermentation and the partitioning of SCFA production is accounted for in most mathematical models used to predict SCFA production (Pitt et al., 1996; Bannink et al., 2006; Loncke et al., 2009), there has been little success relating the production of SCFA to ruminal pH (Pitt et al., 1996). Thus, strategies to quantify the individual SCFA produced are needed to quantify $\mathrm{H}^{+}$release and further understand acid-base balance in the rumen.

\section{IN SITU BUFFERING OF RUMINAL PROTONS}

The production of large amounts of organic acids, especially SCFA, under energy-dense feeding conditions is a nutritionally desirable result of fermentation (Bergman, 1990; Allen, 1997; Gäbel and Aschenbach, 2007). However, a problem can arise from the large amounts of protons that these weak acids release when they dissociate in the ruminal environment (Gäbel and Aschenbach, 2006). The dissociation equilibrium is characterized by the $\mathrm{p} K_{\mathrm{a}}$ value [where $\mathrm{p} K_{\mathrm{a}}$ is $-\log \left(K_{\mathrm{a}}\right)$ and $K_{\mathrm{a}}$ is the acid dissociation constant]. Considering that $\mathrm{p} K_{\mathrm{a}}$ $=4.8$ for SCFA (Table 1), it can be calculated from the Henderson-Hasselbalch equation that 1, 10, 50, 90, and $99 \%$ of SCFA have released their protons at $\mathrm{pH}$ $2.8,3.8,4.8,5.8$, and 6.8, respectively. As such, SCFA themselves behave like a buffer system that can release protons when $\mathrm{pH}$ increases and bind protons when $\mathrm{pH}$ decreases. From the above sample calculation according to Henderson-Hasselbalch, it is also evident that the largest part of the buffering capacity (i.e., 80\%) resides in the $\mathrm{pH}$ range of $\mathrm{p} K_{\mathrm{a}} \pm 1$. The problem with the SCFA buffer is that it would effectively stabilize ruminal $\mathrm{pH}$ toward pH 4.8 (Counotte et al., 1979), which is the typical scenario when SCFA concentration increases in animals experiencing SARA (Stone, 2004; Krause and Oetzel, 2006). Short-chain fatty acid concentrations often increase to $>150 \mathrm{mmol} / \mathrm{L}$ (DeFrain et al., 2002; Morgante et al., 2007) with a negative relationship between the ruminal concentration of SCFA and ruminal pH (Kolver and de Veth, 2002). The situation may become worse when rumen fermentation changes at very high amounts of concentrate feeding, when SCFA are gradually replaced by lactate. Lactate has a $\mathrm{p} K_{\mathrm{a}}$ value of 3.86 (Table 1) and, thus, stabilizes pH about 1 unit less than an SCFA-buffered system (Stone, 2004). In contrast to SCFA, lactate is only very slowly absorbed from the rumen (Williams and Mackenzie, 1965; see subsequent discussion) and does not require increased production rates to accumulate to greater intraruminal concentrations. An accumulation of $\geq 5 \mathrm{mmol} / \mathrm{L}$ lactate has been suggested as the threshold to predispose a ruminant to acute ruminal acidosis (Nocek, 1997).

Because the organic acids produced during fermentation would inevitably buffer the ruminal content to low $\mathrm{pH}$ values, the rumen must be supplied with additional buffer bases to increase luminal $\mathrm{pH}$ into a range that is more compatible with microbial and host life. The repertoire of available buffer substances is listed in Table 1. In this section, we will largely focus on $\mathrm{HCO}_{3}{ }^{-}$and $\mathrm{HPO}_{4}{ }^{2-}$ as the quantitatively most important buffer bases (Counotte et al., 1979; Allen, 1997). The role of $\mathrm{NH}_{3}$ will be explored in a subsequent discussion toward the end of this review.

Saliva is one important source of buffer bases (Counotte et al., 1979; Erdman, 1988; Maekawa et al., 2002), especially the voluminous secretion from the parotid glands (Coats and Wright, 1957; Kay, 1960). The alkalinity of ruminant saliva has been known for almost 200 yr (Tiedemann and Gmelin, 1826) and its relevance for ruminal acid-base balance has been discussed for about 100 yr (Markoff, 1913; Scheunert and Trautmann, 1921). Ruminant saliva contains phosphate and bicarbonate in concentrations that are far greater than those in nonruminant species, making it an appropriate medium for buffering the acids produced in the rumen (McDougall, 1948; Turner and Hodgetts, 1955). Phosphate has typical concentrations in bovine mixed saliva of $\sim 20$ to $30 \mathrm{mmol} / \mathrm{L}$ (Bailey and Balch, 1961). Total phosphate secretion into the rumen may thus reach $\sim 6$ $\mathrm{mol} / \mathrm{d}$ in lactating dairy cows, with peak salivary secretion rates of $\sim 250 \mathrm{~L} / \mathrm{d}$ (Cassida and Stokes, 1986; Erdman, 1988; Maekawa et al., 2002). The $\mathrm{HPO}_{4}{ }^{2-} / \mathrm{H}_{2} \mathrm{PO}_{4}{ }^{-}$ 
Table 1. Buffering systems in the rumen

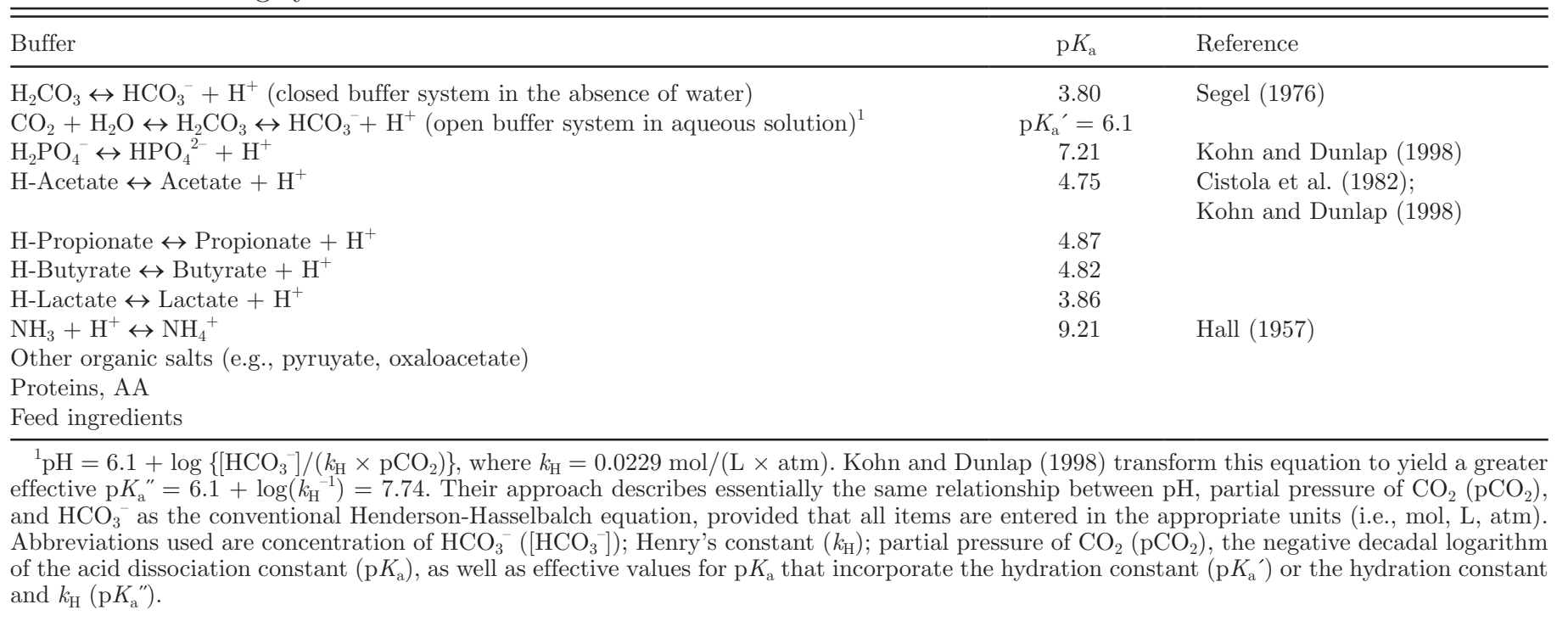

buffer has a $\mathrm{p} K_{\mathrm{a}}$ of 7.21 (Table 1), meaning that $80 \%$ of the buffering capacity resides in the $\mathrm{pH}$ range between 8.21 and 6.21 (i.e., $\mathrm{p} K_{\mathrm{a}} \pm 1$ ). Given that typical $\mathrm{pH}$ in mixed saliva of a cow is 8.2 to 8.5 (Emery et al., 1960; Bailey and Balch, 1961; Cassida and Stokes, 1986) and with an assumed ruminal $\mathrm{pH}$ of 6.2 or less, $\geq 80 \%$ of buffering capacity of phosphate may be used when saliva is mixed with the ruminal content. This means that phosphate would buffer $\sim 5 \mathrm{~mol} / \mathrm{d}$ protons in the rumen of the aforementioned dairy cow. An even greater buffering capacity resides in salivary $\mathrm{HCO}_{3}{ }^{-}$with typical concentrations in bovine mixed saliva of $\sim 120 \mathrm{mmol} / \mathrm{L}$ (Bailey and Balch, 1961; Erdman, 1988). At peak salivary secretion rates of $\sim 250 \mathrm{~L} / \mathrm{d}$, total $\mathrm{HCO}_{3}^{-}$secretion into the dairy cow rumen may reach $30 \mathrm{~mol} / \mathrm{d}$. The ruminal $\mathrm{HCO}_{3}^{-}$system is more complex than the SCFA and phosphate buffering systems. The buffering capacity of $\mathrm{HCO}_{3}{ }^{-}$cannot simply be deduced from the $\mathrm{p} K_{\mathrm{a}}$ of the pure $\mathrm{HCO}_{3}{ }^{-} / \mathrm{H}_{2} \mathrm{CO}_{3}$ equilibrium $\left(\mathrm{p} K_{\mathrm{a}}=3.8\right.$; Table 1 ) because this equilibrium is part of a double-open system in the rumen. The first opening to increase the efficiency of $\mathrm{HCO}_{3}{ }^{-}$buffering is that $\mathrm{H}_{2} \mathrm{CO}_{3}$ can decay to $\mathrm{H}_{2} \mathrm{O}$ and $\mathrm{CO}_{2}$ and is thus in equilibrium with the dissolved $\mathrm{CO}_{2}$ in the ruminal fluid. The concentration of dissolved $\mathrm{CO}_{2}\left(\left[\mathrm{CO}_{2}\right]\right)$ can be calculated from the partial pressure of $\mathrm{CO}_{2}\left(\mathrm{pCO}_{2}\right)$ multiplied by Henry's constant $\left[\mathrm{k}_{\mathrm{H}}=0.0229 \mathrm{~mol} /(\mathrm{L} \times\right.$ atm $\left.)\right]$. Because only about $0.5 \%$ of the dissolved $\mathrm{CO}_{2}$ combines with water to form $\mathrm{H}_{2} \mathrm{CO}_{3}$, the negative log of the hydration constant $(-\log 0.005=2.3)$ has to be added to the $\mathrm{p} K_{\mathrm{a}}$ value of pure carbonic acid. Therefore, the resulting Hendersson-Hasselbalch equilibrium between $\mathrm{HCO}_{3}^{-}$ and dissolved $\mathrm{CO}_{2}$ has an effective $\mathrm{p} K_{\mathrm{a}}{ }^{\prime}$ of 6.1 (Table 1 ) and is described by $\mathrm{pH}=6.1+\log \left\{\left[\mathrm{HCO}_{3}{ }^{-}\right] /\left(\mathrm{k}_{\mathrm{H}} \times\right.\right.$ $\left.\left.\mathrm{pCO}_{2}\right)\right\}$ (Segel, 1976). A special feature of the rumen is that the dissolved $\mathrm{CO}_{2}$ may escape into a gas phase and is eventually eructated or absorbed (Kohn and Dunlap, 1998). As one reaction partner is steadily diluted out of the system, the efficiency of $\mathrm{HCO}_{3}{ }^{-}$buffering increases a second time. This double-open system is a big advantage for the animal because the buffering capacity of saliva is greatly increased. A rough estimate indicates that the true percentage of $\mathrm{HCO}_{3}^{-}$converted to $\mathrm{CO}_{2}$ is in excess of $90 \%$ in the double-open system. For example, the concentration of $\mathrm{HCO}_{3}^{-}$in the ruminal fluid amounts to $16 \mathrm{mmol} / \mathrm{L}$ at steady-state ruminal $\mathrm{pH}$ of 6.1. Assuming a salivary bicarbonate entry of $120 \mathrm{mmol} / \mathrm{L}$ and that salivary secretion rate roughly equals the liquid passage rate (Allen, 1997; Maekawa et al., 2002), $87 \%$ [i.e., $(120-16) / 120 \%$ ] of salivary bicarbonate would have been used to buffer protons. Considering further that the ruminal epithelium contributes to the ruminal $\mathrm{HCO}_{3}{ }^{-}$concentration by secreting $\mathrm{HCO}_{3}^{-}$in amounts that are roughly comparable with salivary $\mathrm{HCO}_{3}^{-}$secretion (see subsequent discussion), the percentage of $\mathrm{HCO}_{3}^{-}$converted to $\mathrm{CO}_{2}$ increases well above $90 \%$ [e.g., $(120-8) / 120 \%$ ]. For a model cow with $30 \mathrm{~mol} / \mathrm{d}$ salivary bicarbonate, this means that $\sim 27 \mathrm{~mol} / \mathrm{d}$ are used to buffer ruminal protons. Salivary phosphate and bicarbonate buffers thus may bind up to $\sim 40 \%$ of the ruminally released protons in high-yielding dairy cows (Allen, 1997).

Despite the undisputed importance of saliva in ruminal $\mathrm{H}^{+}$buffering, conflicting results have been obtained regarding the acidosis protection provided by saliva. In one study using 4 different energy-dense feeding conditions, increased rates of salivary secretion were paradoxically associated with increased severity of SARA (Penner and Beauchemin, 2010; Figure 3). Therefore, mechanisms other than salivary buffer secretion may be more decisive for SARA protection. These mechanisms likely reside in the ruminal epithelium. The importance of the ruminal epithelium as a buffer source for the ruminal content was acknowledged much later than the importance of saliva. The ruminal epithelium itself secretes large amounts of $\mathrm{HCO}_{3}{ }^{-}$(Gäbel et al., 1991a) and removes protonated buffer bases with a low $\mathrm{p} K_{\mathrm{a}}$ [i.e., protonated SCFA (HSCFA); Gäbel and As- 


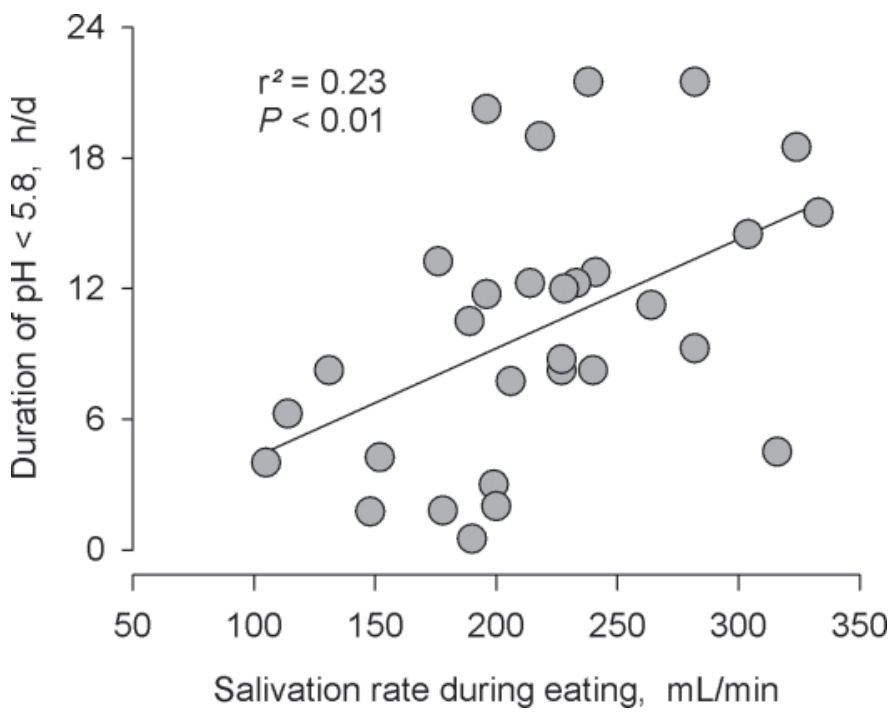

Figure 3. Relationship between the duration that ruminal $\mathrm{pH}$ is $<5.8$ and the rate of saliva production during eating in lactating dairy cows. Data are from 8 cows receiving 4 acidogenic diets containing between 40 and $60 \%$ concentrate in a double $4 \times 4$ Latin square design. Diet itself did not affect salivation rate during eating or the duration of $\mathrm{pH}<5.8$ (for details, see Maekawa et al., 2002). However, a positive correlation existed between salivation rate during eating and the duration of $\mathrm{pH}<5.8$. It indicates that the duration that $\mathrm{pH}$ is $<5.8$ cannot be ameliorated by increasing the rate of salivary secretion under acidogenic feeding conditions. Adapted from Penner and Beauchemin (2010)

chenbach, 2006, 2007]. Both processes contribute to the stabilization of ruminal $\mathrm{pH}$ into the physiological range. However, as these issues directly relate to the absorption of SCFA, they will be discussed subsequently.

\section{PROTON REMOVAL BY ACID ABSORPTION}

Almost exactly $100 \mathrm{yr}$ after the first description of ruminal microbes (Gruby and Delafond, 1843), pioneering experiments were performed in Cambridge showing that a major part of microbially produced SCFA is directly absorbed across the forestomach wall (Phillipson and McAnally, 1942; Barcroft et al., 1944). This initiated a series of experiments extending the understanding of the role of the rumen from a mere fermentation chamber to an absorptive organ as well (Danielli et al., 1945; Masson and Phillipson, 1951; Ash and Dobson, 1963). Today, it is widely accepted that between 50 to $85 \%$ of the ruminally produced SCFA is directly absorbed across the reticuloruminal wall; only 15 to $50 \%$ passes into distal parts of the digestive system. The percentage that is not absorbed in the reticulorumen and passes into distal parts appears to be least in sheep (15\%; von Engelhardt and Hauffe, 1975) and calves (15 to $20 \%$; Edrise and Smith, 1977). Dairy cows and steers have fractional SCFA passage rates typically between 29 and 39\% (Tamminga and van Vuuren, 1988; Peters et al., 1990; Penner et al., 2009c). Although energy intake clearly determines the absolute amount of SCFA available for absorption versus passage, there is no lin- ear relationship between energy intake (Penner et al., 2009c) or SCFA production rates (Peters et al., 1990) and fractional SCFA passage into the omasum. This is because the "spillover" of the excess acids into the omasum will be counteracted by 1) increased ruminal absorption rates of SCFA at a lower ruminal pH (Dijkstra et al., 1993) and 2) decreased liquid passage rates into the omasum (Colucci et al., 1990) under energydense feeding conditions. However, extreme energy intakes (4 times maintenance vs. maintenance) have been found to enhance the fraction of SCFA passing unabsorbed into the omasum (Tamminga and van Vuuren, 1988). Decreased ruminal motility due to low ruminal $\mathrm{pH}$ could contribute to the latter phenomenon because the mixing of ruminal contents is an important factor favoring absorption (Allen et al., 2006). The greatest fractional passage rates (about 50\%) have been reported in dairy cows in early lactation on fresh grass and concentrate feeding (Resende Júnior et al., 2006), which may, in part, be related to greater liquid passage rates associated with diets based on fresh forage (Reis and Combs, 2000). The fractional passage rates of SCFA, however, cannot be set equal to passage of protons into distal compartments because only a small fraction of the passing acids will carry a proton (e.g., 1\% of SCFA at $\mathrm{pH}$ 6.8). Allen (1997) estimated the proton removal from the rumen by passage of HSCFA and other buffering substances (e.g., $\mathrm{H}_{2} \mathrm{PO}_{4}^{-}, \mathrm{NH}_{4}^{+}$, particulate matter) to be on the order of approximately $15 \%$. Given a salivary buffering of up to $\sim 40 \%$ of released protons, as discussed previously, it becomes clear that the majority of protons have to be removed by absorption in most situations.

As elaborated earlier, SCFA absorption proceeds on the order of 50 to $85 \%$ of the produced acids, being equivalent to 40 to $60 \mathrm{~mol} / \mathrm{d}$ in dairy cows fed a high concentrate diet (Allen, 1997; Penner et al., 2009c). Nevertheless, the importance of SCFA absorption for ruminal $\mathrm{pH}$ homeostasis cannot be reduced to a sole quantitative consideration of SCFA absorption rates. For the efficiency of concurrent proton removal, the mechanism of absorption deserves due consideration (Figure 4). From current perspective, it is very intriguing that the very early studies on ruminal SCFA absorption already elucidated some important characteristics of ruminal SCFA absorption; that is, the chain length (Danielli et al., 1945; Gray, 1947) and pH dependence of absorption (Gray, 1948), the partial metabolism of SCFA during absorption (butyrate $>$ propionate > acetate; Masson and Phillipson, 1951), the contribution of SCFA absorption to ruminal $\mathrm{pH}$ stabilization (Masson and Phillipson, 1951; Ash and Dobson, 1963), and the appearance of bicarbonate in the rumen when SCFA are absorbed (Ash and Dobson, 1963). Research over the last $50 \mathrm{yr}$ extended these early findings and provided functional explanations by using in vitro (Pennington, 1951; Hird and Weidemann, 1964; Hird et al., 1966; Stevens and Stettler, 1966a,b, 1967) and molecular techniques (Müller et al., 2002; Lane et al., 


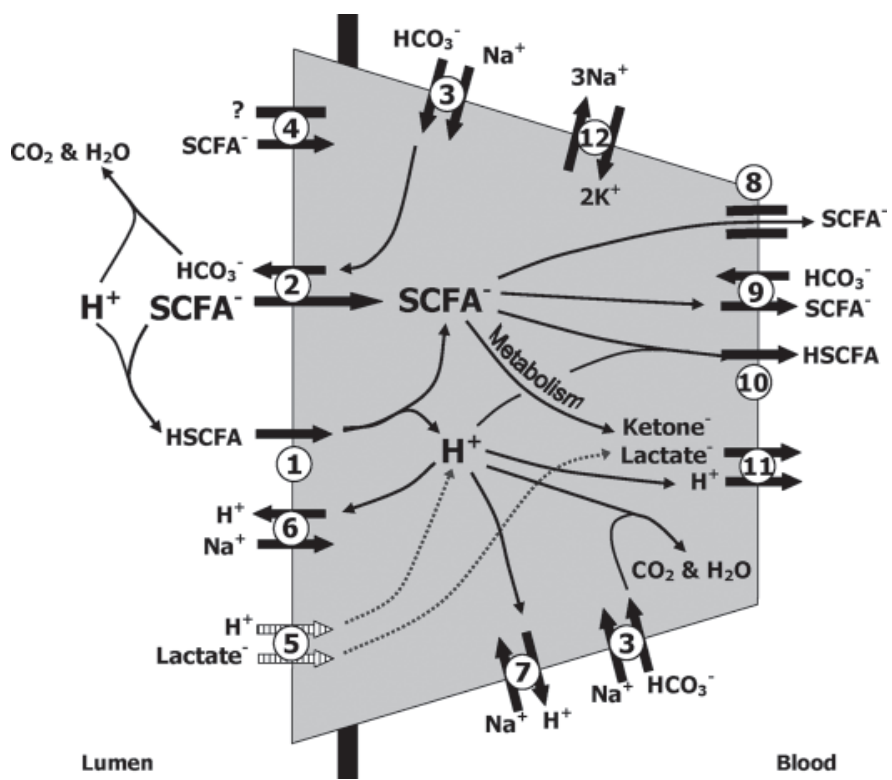

Figure 4. Model on organic acid transport in ruminal epithelial cells. On the lumen-directed apical membrane, lipophilic diffusion of undissociated short-chain fatty acids (HSCFA; 1 ) is an efficient way to import acids with high lipophilicity (especially butyric acid) into the cell. These acids rapidly release their protons once inside the cell. All 3 short-chain fatty acids (SCFA; i.e., acetic, propionic, and butyric acids) additionally use transport proteins that exchange their anions (SCFA ${ }^{-}$) with $\mathrm{HCO}_{3}{ }^{-}$for apical uptake (2). The $\mathrm{SCFA}^{-} / \mathrm{HCO}_{3}{ }^{-}$exchange is especially important for acids with less lipophilicity, such as acetate, and is largely driven by $\mathrm{HCO}_{3}{ }^{-}$imported from the blood via $\mathrm{Na}^{+} / \mathrm{HCO}_{3}{ }^{-}$cotransport (3). The apically exported $\mathrm{HCO}_{3}^{-}$neutralizes 1 proton in the rumen; therefore, lipophilic diffusion and $\mathrm{SCFA}^{-} /$ $\mathrm{HCO}_{3}{ }^{-}$exchange have a largely comparable contribution to ruminal proton removal. The acetate anion may additionally use a poorly characterized apical uptake protein with undefined role for ruminal $\mathrm{pH}$ homeostasis (4). Lactate anions can enter the cell in cotransport with their protons (5). However, the responsible monocarboxylate cotransporter has an extremely low functional activity in roughage-adapted sheep and its quantitative importance remains to be determined. Protons taken up with HSCFA or lactic acid can either be neutralized by $\mathrm{HCO}_{3}^{-}$from basolateral $\mathrm{Na}^{+} / \mathrm{HCO}_{3}^{-}$cotransport (3) or expelled by $\mathrm{Na}^{+} / \mathrm{H}^{+}$exchange across the apical (6) or basolateral membrane (7). The pathways of basolateral exit of SCFA have not been evaluated in detail but are likely to include an anion channel permeable to large anions (8), $\mathrm{SCFA}^{-} / \mathrm{HCO}_{3}{ }^{-}$exchange (9), and lipophilic diffusion (10). Of these, $\mathrm{SCFA}^{-} / \mathrm{HCO}_{3}{ }^{-}$exchange and lipophilic diffusion would contribute to net removal of protons from the epithelial cell into the blood. Butyrate is metabolized extensively to ketone bodies (i.e., $\beta$-hydroxybutyrate, acetoacetate) and propionate is metabolized partly to lactate inside the cells. These metabolic products and possibly apically imported lactate are expelled together with their protons across the basolateral membrane via monocarboxylate transporter 1 (MCT1) (11). All $\mathrm{Na}^{+}$-driven transport mechanisms are energized by the $\mathrm{Na}^{+} /$ $\mathrm{K}^{+}$ATPase (12) at the basolateral membrane. The electrogenic efflux of $\mathrm{Na}^{+}$via this pump requires a neutralizing efflux of anions through the basolateral anion channel (8). The $\mathrm{HCO}_{3}{ }^{-}$and $\mathrm{H}^{+}$pool inside ruminal epithelium is partly replenished from $\mathrm{CO}_{2}$ by carbonic anhydrase reaction (Gäbel et al., 2002), which is not shown in the current model for clarity reasons.

2002; Bilk et al., 2005). As a result, we realize today that absorption of SCFA from the rumen is not purely determined by energy input, microbial dynamics, and physicochemical factors. The ruminal epithelium itself is a dynamic key player with a major contribution to decreasing the ruminal acid and proton load.

The current model on ruminal SCFA absorption is depicted in Figure 4. Absorption of undissociated HSCFA via lipophilic diffusion has long been postu- lated to be the only relevant pathway of SCFA absorption (Bugaut, 1987; López et al., 2003; Graham et al., 2007). Because the permeability of lipid bilayer membranes to the electrically charged SCFA anion $\left(\mathrm{SCFA}^{-}\right)$ is extremely low, passive diffusion has to be attributed to the lipophilic protonated form, HSCFA (Walter and Gutknecht, 1986; Gäbel et al., 2002). Lipophilic diffusion couples the removal of $\mathrm{SCFA}^{-}$anions to the removal of protons at a ratio of $1: 1$, which constitutes a very efficient way of proton extraction from the rumen (Allen, 1997). However, quantitative and qualitative constraints indicate that lipophilic diffusion cannot be the only way of SCFA absorption. A quantitative constraint to lipophilic diffusion is that HSCFA $\left(\mathrm{p} K_{\mathrm{a}} \sim 4.8\right.$; Table 1) constitute only a small fraction in the HSCFASCFA $^{-}$acid-base equilibrium according to HendersonHasselbalch's equation; for example, only $1 \%$ at pH 6.8 . Consequently, the effective luminal concentration driving apical uptake of total HSCFA may be as little as $1 \mathrm{~m} M$. A qualitative constraint is that the acid production rates discussed previously (i.e., acetic $>$ propionic $>$ butyric acid) are inversely related to their lipophilic permeability (i.e., butyric $>$ propionic $>$ acetic acid). For example, lipid bilayer permeability decreases from butyric to acetic acid by a factor of approximately 14 (Walter and Gutknecht, 1986). A second qualitative constraint is that the rates of intracellular metabolism (i.e., butyric $>$ propionic $\geq$ acetic acid; Bergman, 1990; Kristensen et al., 2000; Kristensen and Harmon, 2004) that finally enhance lipophilic diffusion by decreasing the intracellular acid concentration are also inversely related to acid production rates. Together, the 2 qualitative constraints would inevitably lead to selective sequestration of large amounts of acetate in the rumen. The latter is in sharp contrast to experimental data showing that all 3 SCFA are absorbed at rather comparable fractional rates from the ovine (Kristensen et al., 2000; Aschenbach et al., 2009) and bovine rumen at physiological ruminal pH (Dijkstra et al., 1993; Kristensen and Harmon, 2004, 2005) in vivo. Therefore, it is essential to postulate additional routes of absorption, at least, for acetic and propionic acids, that is, for acids with decreased rates of lipophilic absorption and intraepithelial metabolism compared with butyric acid.

Nondiffusional absorption of SCFA requires transport proteins and applies to the dissociated anions, SCFA ${ }^{-}$. The main pathway for apical nondiffusional absorption of $\mathrm{SCFA}^{-}$has meanwhile been clearly identified as $\mathrm{SCFA}^{-} / \mathrm{HCO}_{3}^{-}$exchange (Gäbel et al., 1991a; Kramer et al., 1996; Aschenbach et al., 2009; Figure 4). Acetate, especially, seems to utilize $\mathrm{HCO}_{3}{ }^{-}$-dependent uptake for absorption (Ash and Dobson, 1963; Aschenbach et al., 2009; Penner et al., 2009a). Masson and Phillipson (1951) already had discovered that the absorption of SCFA leads to $\mathrm{HCO}_{3}^{-}$enrichment in the rumen. However, this phenomenon was initially explained by carbonic acid dissociation that served to provide protons for a diffusive uptake of HSCFA, leaving $\mathrm{HCO}_{3}^{-}$behind in the rumen (Ash and Dobson, 1963). Later, a 

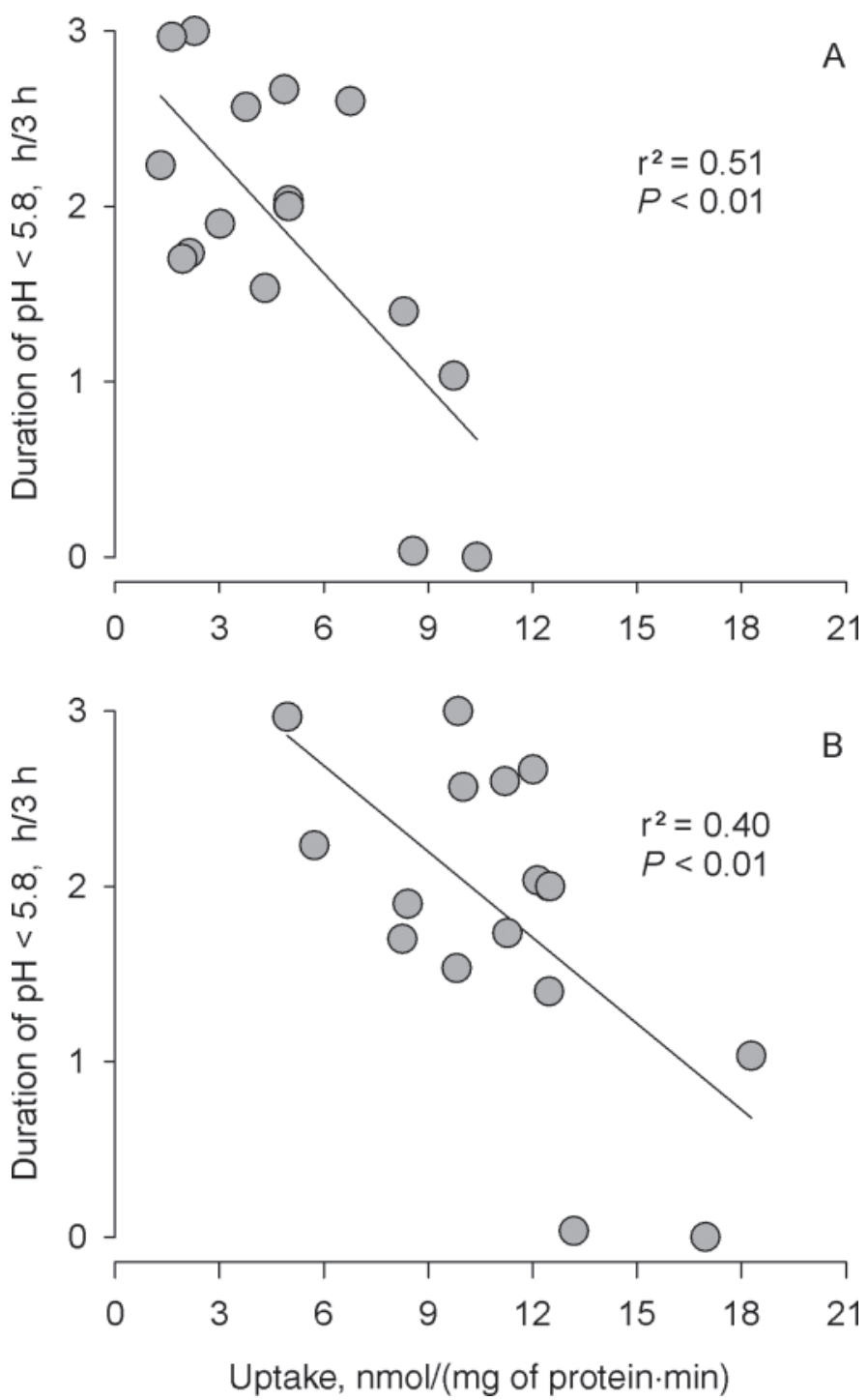

Figure 5. Relationship between acetate (panel A) and butyrate uptake (panel B) across the apical membrane of ruminal epithelial cells and the duration spent at ruminal $\mathrm{pH}<5.8$. Uptake of short-chain fatty acids (SCFA) was measured in isolated ruminal epithelia at a concentration of $10 \mathrm{~m} M$ each. Donor sheep of these epithelia had been subjected to a defined induction protocol for subacute ruminal acidosis (SARA) in vivo for $3 \mathrm{~h}$ (oral drench of $5 \mathrm{~g}$ of glucose $/ \mathrm{kg}$ of BW; for details see Penner et al., 2009a). The incidence of SARA, represented by the duration of $\mathrm{pH}<5.8$, decreases markedly when ruminal epithelia are able to take up larger quantities of acetate and butyrate. An $\mathrm{r}^{2}$ of $\sim 0.5$ indicates that $\sim 50 \%$ of the individual susceptibility to SARA can be explained based on the absorptive capacity of the ruminal epithelium for these acids.

weak inhibitory effect of the unspecific anion transport blocker $\quad 4,4^{\prime}$-diisothiocyanatostilbene-2,2'-disulfonic acid on propionate fluxes in the ovine rumen (Kramer et al., 1996) and butyrate fluxes in the bovine rumen (Sehested et al., 1999) indicated the existence of some direct $\mathrm{SCFA}^{-} / \mathrm{HCO}_{3}^{-}$exchange. The final proof for direct coupling between $\mathrm{SCFA}^{-}$absorption and $\mathrm{HCO}_{3}$ secretion was recently deduced from the finding that the long-known stimulatory effect of low ruminal $\mathrm{pH}$ on SCFA absorption is, to a major extent, attributable to a $\mathrm{HCO}_{3}{ }^{-}$gradient across the apical membrane and not to the $\mathrm{pH}$ gradient itself. In the absence of $\mathrm{HCO}_{3}^{-}$, the stimulatory effect of $\mathrm{pH}$ on acetate uptake is negligible (Aschenbach et al., 2009). Furthermore, the latter studies indicated that apically exported $\mathrm{HCO}_{3}{ }^{-}$is replenished to a significant degree from extracellular sources, which indicates that $\mathrm{HCO}_{3}{ }^{-}$secretion by the ruminal epithelium involves apical $\mathrm{SCFA}^{-} / \mathrm{HCO}_{3}{ }^{-}$exchange and basolateral $\mathrm{Na}^{+} / \mathrm{HCO}_{3}{ }^{-}$cotransport operating in series (Huhn et al., 2003; Aschenbach et al., 2009; Figure 4).

Quantitative estimates from sheep indicate that up to $50 \%$ of the SCFA can be absorbed in a $\mathrm{HCO}_{3}{ }^{-}$-dependent manner (Ash and Dobson, 1963; Gäbel et al., 1991a; Penner et al., 2009a). Extrapolating these quantities to high-yielding dairy cows would mean that the ruminal epithelium supplies an amount of $\mathrm{HCO}_{3}^{-}$to the ruminal content that is roughly equivalent to salivary $\mathrm{HCO}_{3}{ }^{-}$secretion (i.e., 20 to $30 \mathrm{~mol} / \mathrm{d}$ ). The ruminally secreted $\mathrm{HCO}_{3}{ }^{-}$enters the double-open $\mathrm{HCO}_{3}{ }^{-}$buffer system of the rumen where it combines with $\mathrm{H}^{+}$to form $\mathrm{CO}_{2}$ and water (Figure 4). In this way, the exchange of 1 mol SCFA against $1 \mathrm{~mol} \mathrm{HCO}_{3}^{-}$finally also leads to the neutralization of $>0.9 \mathrm{~mol} \mathrm{H}^{+}$in the ruminal content (for estimation of $\mathrm{HCO}_{3}{ }^{-}$buffering capacity; see previous section). Animals with very efficient SCFA absorption may utilize a third absorptive mechanism, which is protein-mediated but $\mathrm{HCO}_{3}{ }^{-}$-independent (Penner et al., 2009a; Figure 4). Even if this third mechanism would not coeliminate ruminal protons, $\mathrm{SCFA}^{-} / \mathrm{HCO}_{3}{ }^{-}$ exchange and lipophilic diffusion alone remove $\mathrm{H}^{+}$in quantities that exceed $\mathrm{H}^{+}$removal by saliva. Absorption of SCFA also means an extraction of low-p $K_{\mathrm{a}}$ buffers from the ruminal content. It is thus not surprising that the individual susceptibility of sheep to SARA is negatively correlated to their ruminal capacity for apical SCFA uptake (Penner et al., 2009a; Figure 5).

For ruminal $\mathrm{pH}$ homeostasis, 2 factors are important: how many protons are removed with $\mathrm{SCFA}^{-}$during absorption and how permanent the proton extraction is. Both the inflow of HSCFA into ruminal epithelial cells and the outflow of $\mathrm{HCO}_{3}^{-}$via $\mathrm{SCFA}^{-} / \mathrm{HCO}_{3}{ }^{-}$exchange decrease intracellular $\mathrm{pH}\left(\mathbf{p H}_{\mathbf{i}}\right)$ in isolated ruminal epithelial cells (Müller et al., 2000; Gäbel et al., 2002), as well as intact ruminal epithelium (Abdoun et al., 2010). In principle, the ruminal epithelium can counterregulate $\mathrm{pH}_{\mathrm{i}}$ acidification via basolateral acid-base transporters, which likely include one of the discovered $\mathrm{Na}^{+} /$ $\mathrm{H}^{+}$exchanger (NHE) isoforms (Müller et al., 2000; Gäbel and Aschenbach, 2006; Etschmann et al., 2006) as well as basolateral $\mathrm{Na}^{+} / \mathrm{HCO}_{3}{ }^{-}$import (Huhn et al., 2003; Figure 4). However, a proven and significant part of $\mathrm{pH}_{\mathrm{i}}$ regulation occurs by exporting protons back into the lumen via an apical NHE (Sehested et al., 1996; Müller et al., 2000; Gäbel et al., 2002). Both ruminal SCFA absorption (Gäbel et al., 1991b) and $\mathrm{Na}^{+}$supply by saliva (Sehested et al., 1996) increase the driving forces for this apical NHE and, thus, contribute to $\mathrm{H}^{+}$ recycling. According to our current definition of SARA, based on ventral ruminal $\mathrm{pH}$, we would need to regard apical NHE as a mechanism contributing to SARA because it increases the ruminal proton load to $>100 \%$ 
of initial proton release. In fact, however, it protects the animal from the negative consequences of SARA by securing epithelial cell function and by preventing $\mathrm{Na}^{+}$accumulation in the rumen, the latter counteracting the vicious cycle of rising osmolarity, rising volume, and decreasing $\mathrm{pH}$ seen in SARA.

The apical uptake of SCFA is one important ratelimiting step during SCFA absorption with a clear role in acidosis protection (Penner et al., 2009a; Figure 5). Less is known about the basolateral exit pathways. Only monocarboxylate transporter 1 (MCT1) has been unequivocally localized to the basolateral membrane (Müller et al., 2002; Kirat et al., 2006; Graham et al., 2007). It is involved in the basolateral export of ketone bodies arising from the intracellular metabolism of butyrate and for lactate arising from metabolism of propionate (Müller et al., 2002; Gäbel and Aschenbach, 2006). The velocity of butyrate metabolism to ketone bodies and the consecutive export across the basolateral membrane via MCT1 are accepted determinants for the velocity of butyrate and proton removal from the rumen (Gäbel et al., 2001; Penner et al., 2009a). Some authors also consider a direct export of SCFA via MCT1 (Kirat et al., 2006; Graham et al., 2007). Alternative pathways for basolateral export of SCFA would be lipophilic diffusion (Gäbel et al., 2002; Gäbel and Aschenbach, 2006) and $\mathrm{SCFA}^{-} / \mathrm{HCO}_{3}{ }^{-}$exchange (Bilk et al., 2005). All 3 mechanisms (i.e., MCT1, lipophilic diffusion, and $\mathrm{SCFA}^{-} / \mathrm{HCO}_{3}{ }^{-}$exchange) would coeliminate a proton from the cytosol to blood. However, a plausibility check leads to the conclusion that some SCFA have to leave the cell as a free base without a proton, because a considerable fraction of protons is buffered in the rumen by saliva. In addition, the cellalkalizing action of apical and basolateral NHE, as well as that of the $\mathrm{Na}^{+} / \mathrm{HCO}_{3}{ }^{-}$cotransporter, would not be required if apical $\mathrm{H}^{+}$import with $\mathrm{SCFA}^{-}$was equal to basolateral $\mathrm{H}^{+}$export with $\mathrm{SCFA}^{-}$. The $\mathrm{SCFA}^{-}$export without a proton is most likely realized by a large-conductance anion channel in the basolateral membrane (Stumpff et al., 2009) and should be highly efficient in minimizing the SCFA concentration within the cytosol because the efflux is driven by the basolateral membrane potential.

Although the knowledge on quantitative and qualitative aspects of SCFA elimination from rumen has greatly increased over the last decades, the capacity of the ruminal epithelium to absorb lactic acid is still insufficiently assessed. The epithelium possesses an apical MCT, which is likely the MCT4 isoform (Kirat et al., 2007; Aschenbach et al., 2009). This mechanism can extract 1 proton together with each molecule of lactic acid from the rumen (Figure 4). However, the transport velocity of the apical MCT is extremely low in roughage-adapted sheep (Aschenbach et al., 2009), which conforms to the low lactate absorption rates observed in vivo (Williams and Mackenzie, 1965) and can explain the rapid accumulation of lactic acid in times of enhanced lactic acid production (i.e., during acute ruminal acidosis; McLaughlin et al., 2009; Lettat et al., 2010). However, it is an important question whether or not an adaptation of this transport system to concentrate diets occurs and whether this contributes to the acidosis resistance of concentrate-fed ruminants. This question cannot be answered at present. So far, only one study exists about a possible feed adaptation of ruminal MCT4, which could not detect any difference of ruminal MCT4 protein abundance in reindeer fed in captivity versus those on natural pasture (Koho et al., 2005).

\section{INTERACTION OF AMMONIA AND SCFA}

Ruminal ammonia ("ammonia" will be used in this section to refer to the sum of $\mathrm{NH}_{3}$ and $\mathrm{NH}_{4}{ }^{+}$) is an essential source of nitrogen for microbial growth. Ammonia concentrations may increase within $2 \mathrm{~h}$ after a meal to 20 or $30 \mathrm{mmol} / \mathrm{L}$, dependent on rumen degradable $\mathrm{N}$ intake (Reynolds and Kristensen, 2008), only to decrease rapidly thereafter due to utilization by ruminal bacteria (35 to $65 \%$ of the decrease), efflux to the omasum ( $\sim 10 \%$ of the decrease), or absorption across the ruminal wall (McDonald, 1948; Kennedy and Milligan, 1980; Siddons et al., 1985; Obara et al., 1991). Portal flux of ammonia can reach approximately 100 $\mathrm{mmol} / \mathrm{kg}$ of $\mathrm{BW}^{0.75}$ per day (Parker et al., 1995). In the liver, ammonia is detoxified to form urea, much of which reenters the rumen via secretion across the ruminal epithelium, supported by some salivary urea secretion (Harmeyer and Martens, 1980; Marini and Van Amburgh, 2003). Upon entering the rumen, urea is reconverted by bacterial urease to release $2 \mathrm{~mol}$ of $\mathrm{NH}_{3}$ per mol of urea (Figure 6). In dairy cows, absorption of ammonia can reach $25 \mathrm{~mol} / \mathrm{d}$ (Delgado-Elorduy et al., 2002), whereas secretion of up to $10 \mathrm{~mol} / \mathrm{d}$ of urea has been observed (Gozho et al., 2008). Unless dietary $\mathrm{N}$ intake is low, urea secretion into the rumen usually greatly exceeds the needs of microbial protein synthesis (Reynolds and Kristensen, 2008). However, the urea secreted in excess of microbial needs increases ruminal $\mathrm{NH}_{3}$, which is a very potent buffer. Because of its high $\mathrm{p} K_{\mathrm{a}}$ value (9.21; Table 1$), \mathrm{NH}_{3}$ immediately binds $\mathrm{H}^{+}$ in equimolar amounts to form $\mathrm{NH}_{4}{ }^{+}$in the ruminal content. For ruminal pH homeostasis, it is decisive which form of ammonia leaves the rumen. Only efflux of $\mathrm{NH}_{4}{ }^{+}$ to the blood would finally remove a proton from the system.

Although the lipid-diffusion theory dominated the debates surrounding the absorption of SCFA for decades, nondiffusional absorption of $\mathrm{NH}_{4}{ }^{+}$across the ruminal epithelium has long been postulated (Gärtner et al., 1961; Gärtner and von Engelhardt, 1964). The lipophilicity of uncharged $\mathrm{NH}_{3}$ is approximately equal to that of uncharged butyric acid (Walter and Gutknecht, 1986) and at $\mathrm{pH}>7$, substantial amounts of ammonia will cross the epithelium in this form. However, under the conditions found physiologically in the rumen, the 


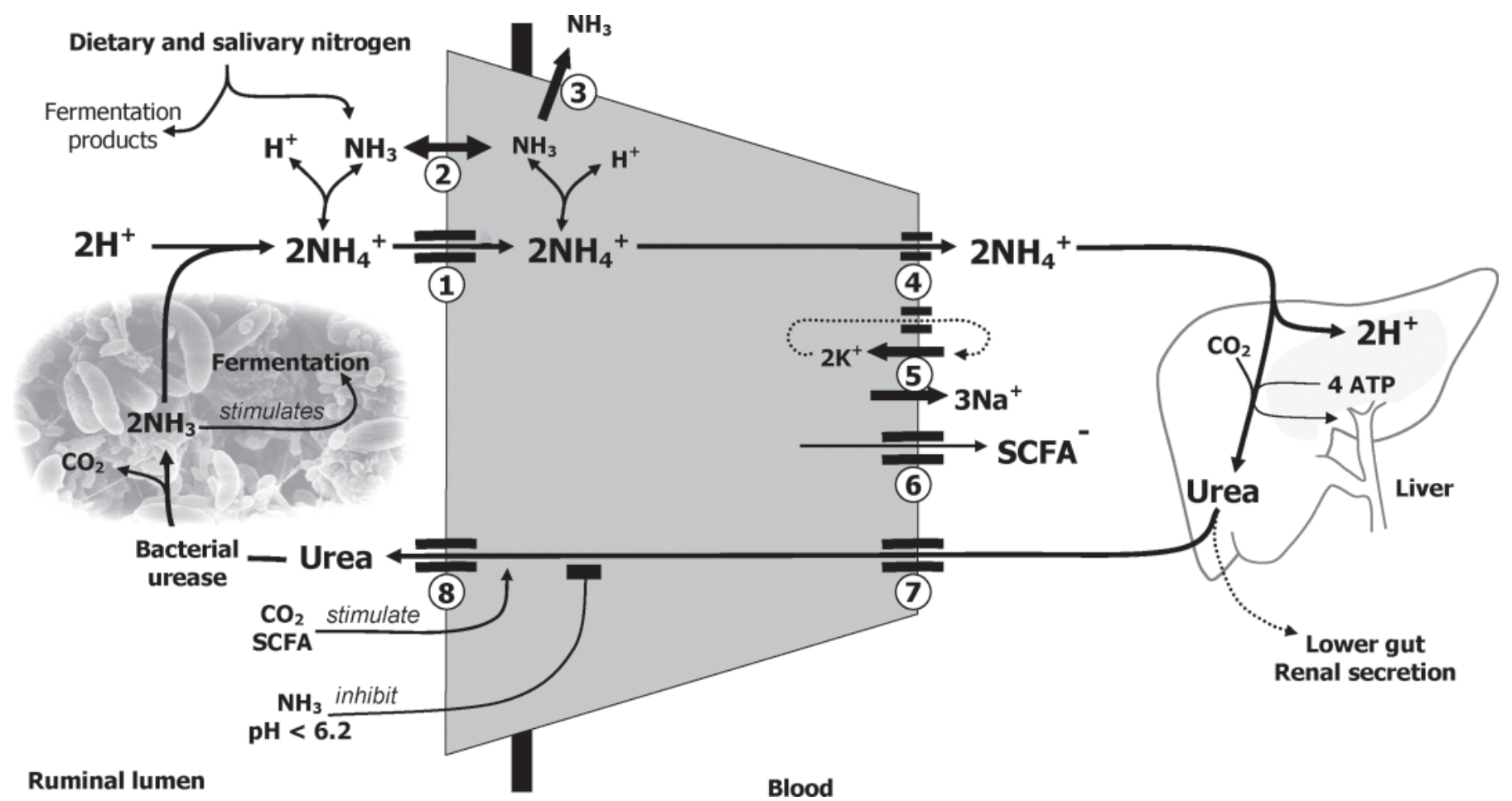

Figure 6. Model on ruminal nitrogen transport and its interaction with short-chain fatty acids (SCFA) and acid-base status. Influx of urea into the rumen and efflux of ammonia influence the amount of nitrogen available for microbial protein synthesis. Excess ammonia is absorbed as $\mathrm{NH}_{4}{ }^{+}$through apical cation channels (1) and as $\mathrm{NH}_{3}(2)$. At $\mathrm{pH}>7$, uptake of $\mathrm{NH}_{3}$ predominates. Within the cytosol, $\mathrm{NH}_{3}$ is protonated to form $\mathrm{NH}_{4}{ }^{+}$, thus reducing the need for the apical extrusion of protons via $\mathrm{Na}^{+} / \mathrm{H}^{+}$exchanger $(\mathrm{NHE})$; compare (6) in Figure 4. At $\mathrm{pH}<6.8$, uptake occurs primarily in the form of $\mathrm{NH}_{4}^{+}$, removing a proton from the rumen directly. Increasing cytosolic concentrations of $\mathrm{NH}_{3}$ within the neutral $\mathrm{pH}$ of the cytosol may result in apical recycling of ammonia (in as $\mathrm{NH}_{4}{ }^{+}$, out as $\mathrm{NH}_{3}$ ), leading to a further uptake of protons that will acidify the cytosol if basolateral efflux occurred as $\mathrm{NH}_{3}$ (3). However, in vitro evidence suggests that large quantities of protons may leave the tissue basolaterally with $\mathrm{NH}_{4}^{+}$through channels necessary for the recirculation of $\mathrm{K}^{+}$(4) from the $\mathrm{Na}^{+} / \mathrm{K}^{+}$ATPase (5). Efflux of SCFA anions (SCFA) through a basolateral anion channel (6) will facilitate the basolateral efflux of $\mathrm{NH}_{4}^{+}$through $\mathrm{K}^{+}$channels (4) via charge-coupling. Within the liver, $\mathrm{NH}_{4}{ }^{+}$is detoxified to form urea, thereby releasing the captured $\mathrm{H}^{+}$. Passage back into the rumen probably occurs via serial urea transporters in the basolateral and apical membranes $(7,8)$ and is regulated according to the requirements of fermentation. At moderately acidic $\mathrm{pH}$, urea influx into the rumen rises with the production of SCFA and $\mathrm{CO}_{2}$, thus supplying nitrogen for microbial growth. When ruminal pH decreases too much or ammonia concentrations increase too much, the permeability of the ruminal wall to urea decreases and urea nitrogen is redirected for excretion in the lower gut or the kidney.

percentage of uncharged $\mathrm{NH}_{3}$ in the Henderson-Hasselbalch equilibrium of $\mathrm{NH}_{3} / \mathrm{NH}_{4}^{+}\left(\mathrm{p} K_{\mathrm{a}}=9.21\right)$ is much less than the percentage of uncharged butyric acid in the butyrate ${ }^{-}$/butyric acid equilibrium $\left(\mathrm{p} K_{\mathrm{a}}=4.82\right.$; Table 1); for example, $\sim 1 / 10$ as much at $\mathrm{pH} 6.5$ and $\sim 1 / 900$ as much at $\mathrm{pH} 5.5$. This implies that decreasing ruminal $\mathrm{pH}$ should impair lipophilic diffusion of $\mathrm{NH}_{3}$ in the same exponential manner with which it stimulates butyric acid diffusion. In contrast to this theory, epithelial uptake of ammonia remains high and may even increase slightly when ruminal $\mathrm{pH}$ decreases in vivo (Gärtner et al., 1961; Siddons et al., 1985; Remond et al., 1993). Electrophysiological data support the conclusion that bulk flow of ammonia proceeds via $\mathrm{NH}_{4}{ }^{+}$at low ruminal $\mathrm{pH}$ when efflux of ammonia from the $\mathrm{ru}-$ men is greatest and extraction of $\mathrm{H}^{+}$becomes important (Bödeker and Kemkowski, 1996; Abdoun et al., 2005). Because the atomic radii of $\mathrm{K}^{+}$and $\mathrm{NH}_{4}{ }^{+}$are strikingly similar (Boron and De Weer, 1976), $\mathrm{NH}_{4}{ }^{+}$most likely passes through the same channels that transport potassium (Bödeker and Kemkowski, 1996; Abdoun et al., 2005) and that are present in both the apical and the basolateral membranes of the ruminal epithelium (Fer- reira et al., 1972; Leonhard-Marek and Martens, 1996). Apically, electrogenic $\mathrm{NH}_{4}{ }^{+}$inflow is supported by the membrane potential that is outside positive. Basolaterally, efflux in the form of $\mathrm{NH}_{4}^{+}$(and thus removal of a proton) is facilitated by the extremely high expression of $\mathrm{K}^{+}$channels necessary for recirculation of $\mathrm{K}^{+}$ entering with the $\mathrm{Na}^{+} / \mathrm{K}^{+}$-ATPase, but has to occur against an electrical gradient. Recent findings indicate that SCFA may play an important role in diminishing this electrical gradient. The outflow of $\mathrm{SCFA}^{-}$through basolateral anion channels should depolarize the basolateral membrane and thereby facilitate the basolateral outflow of $\mathrm{NH}_{4}{ }^{+}$(Stumpff et al., 2009; Figure 6). This suggestion is in line with the classical observation that absorption of luminal ammonia is increased by the copresence of SCFA (Pilgrim et al., 1969; Bödeker et al., 1992; Remond et al., 1993).

Apart from enhancing ammonia absorption, SCFA also increase the secretion of urea (Thorlacius et al., 1971; Norton et al., 1982; Abdoun et al., 2010). Conversely, the permeability of the ruminal wall to urea rapidly declines with greater intraruminal ammonia concentration (Harmeyer and Martens, 1980) or when 
ruminal $\mathrm{pH}$ decreases to $<6.2$ (Abdoun et al., 2010). A regulated protein-mediated pathway for urea has long been postulated (Gärtner et al., 1961). It was initially thought to be identical to the urea transporter-B (Ritzhaupt et al., 1998); however, urea transporter-B is at least not responsible for the large increase in ruminal urea influx capacity induced by low-protein diets, indicating that there are likely additional protein-mediated urea influx pathways (Marini et al., 2004; Muscher et al., 2010; Figure 6).

The interaction of SCFA with the secretion of urea and the absorption of ammonia appear to be important evolutionary adaptations of ruminants to actively regulate the fermentation process. When ruminants are on the low-protein diets of their natural habitats, endogenously secreted nitrogen is a pacemaker of microbial fermentation. The positive effect of SCFA on the secretion of urea allows animals to capitalize on available carbohydrates, while excess ammonia is used to buffer and transfer protons out of the rumen. Conversely, the rate of fermentation can also be reduced to prevent excessive fermentation provided that nitrogen intake is moderate. When $\mathrm{pH}$ declines too much and SCFA accumulate, urea influx decreases (Abdoun et al., 2010), which should decrease microbial growth and the rate of fermentation. Unfortunately, the latter regulatory pathway can be expected to be mostly annulled in high-producing cattle due to excess protein feeding. Nonetheless, the interactions between SCFA, ammonia absorption, and urea secretion are of formidable importance for understanding both the regulation of microbial dynamics and the regulation of ruminal $\mathrm{pH}$.

\section{SUMMARY AND CONCLUSIONS}

Ruminants produce large quantities of organic acids in the rumen when fed on highly fermentable diets. To counteract the development and progression of acidosis, $\mathrm{HCO}_{3}{ }^{-}$inflow into the rumen is the buffer system primarily utilized. Estimates in high-yielding dairy cows indicate that $\mathrm{HCO}_{3}^{-}$is introduced into the rumen to approximately equal shares via saliva and via secretion across the ruminal epithelium. The quantities of $\mathrm{HCO}_{3}{ }^{-}$introduced by saliva and the epithelium may almost be equivalent to total acid production, and it can be expected that $>90 \%$ of $\mathrm{HCO}_{3}^{-}$buffers a proton due to the double-open buffer system of the rumen. The major part of epithelial $\mathrm{HCO}_{3}^{-}$secretion is directly coupled to the absorption of $\mathrm{SCFA}^{-}$. As the ruminal epithelium additionally absorbs HSCFA via lipophilic diffusion and $\mathrm{SCFA}^{-}$via a yet unidentified mechanism, it is the key player in ruminal acid-base balance. This is compatible with the recent finding that the ruminal capacity for absorption of SCFA is a key determinant for the susceptibility of individual animals to acidosis. When estimating the proton load in the rumen, it needs to be considered that a significant fraction of already removed $\mathrm{H}^{+}$is recycled back into the lumen via apical
NHE. The $\mathrm{H}^{+}$recycling is stimulated by both epithelial SCFA absorption and salivary $\mathrm{Na}^{+}$secretion. To better understand the acid-base status of the rumen, it will be vital to assess the quantities of recycled $\mathrm{H}^{+}$at different ruminal $\mathrm{pH}$ in future. Based on our current definition of ruminal acidosis, $\mathrm{H}^{+}$recycling via $\mathrm{NHE}$ has to be regarded as an acidosis-promoting mechanism. In fact, however, it serves to stabilize epithelial integrity and may thus be vital to protect the animal against the negative consequences of acidosis. Another important area for future research is the interaction between SCFA absorption, urea secretion, and $\mathrm{NH}_{4}{ }^{+}$absorption. The better we understand the evolutionary strategy of ruminants to coordinate energy conversion, protein assimilation, and $\mathrm{pH}$ regulation in the rumen, the more successfully we can utilize these processes with due recognition of animal needs and welfare, as well as environmental concerns.

\section{LITERATURE CITED}

Abdoun, K., F. Stumpff, I. Rabbani, and H. Martens. 2010. Modulation of urea transport across sheep rumen epithelium in vitro by SCFA and $\mathrm{CO}_{2}$. Am. J. Physiol. Gastrointest. Liver Physiol. 298:G190-G202.

Abdoun, K., F. Stumpff, K. Wolf, and H. Martens. 2005. Modulation of electroneutral $\mathrm{Na}$ transport in sheep rumen epithelium by luminal ammonia. Am. J. Physiol. Gastrointest. Liver Physiol. 289:G508-G520.

Allen, M. S. 1997. Relationship between fermentation acid production in the rumen and the requirement for physically effective fiber. J. Dairy Sci. 80:1447-1462.

Allen, M. S., J. A. Voelker, and M. Oba. 2006. Physically effective fiber and regulation of ruminal $\mathrm{pH}$ : More than just chewing. Pages $270-278$ in Production Diseases in Farm Animals. N. P. Joshi and T. H. Herdt, ed. Wageningen Academic Publishers, Wageningen, the Netherlands.

AlZahal, O., B. Rustomo, N. E. Odongo, T. F. Duffield, and B. W. McBride. 2007. Technical note: A system for continuous recording of ruminal pH in cattle. J. Anim. Sci. 85:213-217.

Aschenbach, J. R., S. Bilk, G. Tadesse, F. Stumpff, and G. Gäbel. 2009. Bicarbonate-dependent and bicarbonate-independent mechanisms contribute to nondiffusive apical uptake of acetate in the ruminal epithelium of sheep. Am. J. Physiol. Gastrointest. Liver Physiol. 296:G1098-G1107.

Aschenbach, J. R., and G. Gäbel. 2000. Effect and absorption of histamine in sheep rumen: significance of acidotic epithelial damage. J. Anim. Sci. 78:464-470.

Ash, R. W., and A. Dobson. 1963. The effect of absorption on the acidity of rumen contents. J. Physiol. 169:39-61.

Bailey, C. B., and C. C. Balch. 1961. Saliva secretion and its relation to feeding in cattle. 2. The composition and rate of secretion of mixed saliva in the cow during rest. Br. J. Nutr. 15:383-402.

Baldwin, R. L. 1995. Modeling Ruminant Digestion and Metabolism. Chapman \& Hall, London, UK.

Bannink, A., J. France, S. Lopez, W. J. J. Gerrits, E. Kebreab, S. Tamminga, and J. Dijkstra. 2008. Modelling the implications of feeding strategy on rumen fermentation and functioning of the rumen wall. Anim. Feed Sci. Technol. 143:3-26.

Bannink, A., J. Kogut, J. Dijkstra, J. France, E. Krebeab, A. M. Van Vuuren, and S. Tamminga. 2006. Estimation of the stoichiometry of volatile fatty acid production in the rumen of lactating cows. J. Theor. Biol. 238:36-51.

Barcroft, J., R. A. McAnally, and A. T. Phillipson. 1944. Absorption of volatile fatty acids from the alimentary tract of sheep and other animals. J. Exp. Biol. 20:120-129. 
Bergman, E. N. 1990. Energy contributions of volatile fatty acids from the gastrointestinal tract in various species. Physiol. Rev. 70:567-590.

Bevans, D. W., K. A. Beauchemin, K. S. Schwartzkopf-Genswein, J. J. McKinnon, and T. A. McAllister. 2005. Effect of rapid or gradual grain adaptation on subacute acidosis and feed intake by feedlot cattle. J. Anim. Sci. 83:1116-1132.

Bilk, S., K. Huhn, K. U. Honscha, H. Pfannkuche, and G. Gäbel. 2005. Bicarbonate exporting transporters in the ovine ruminal epithelium. J. Comp. Physiol. B 175:365-374.

Bödeker, D., and J. Kemkowski. 1996. Participation of NH4+ in total ammonia absorption across the rumen epithelium of sheep (Ovis aries). Comp. Biochem. Physiol. A Physiol. 114:305310.

Bödeker, D., Y. Shen, J. Kemkowski, and H. Holler. 1992. Influence of short-chain fatty acids on ammonia absorption across the rumen wall in sheep. Exp. Physiol. 77:369-376.

Boron, W. F., and P. De Weer. 1976. Intracellular $\mathrm{pH}$ transients in squid giant axons caused by $\mathrm{CO}_{2}, \mathrm{NH}_{3}$, and metabolic inhibitors. J. Gen. Physiol. 67:91-112.

Brown, M. S., C. R. Krehbiel, M. L. Galyean, M. D. Remmenga, J. P. Peters, B. Hibbard, J. Robinson, and W. M. Moseley. 2000. Evaluation of models of acute and subacute acidosis on dry matter intake, ruminal fermentation, blood chemistry, and endocrine profiles of beef steers. J. Anim. Sci. 78:3155-3168.

Bugaut, M. 1987. Occurrence, absorption and metabolism of short chain fatty acids in the digestive tract of mammals. Comp. Biochem. Physiol. B 86:439-472.

Cassida, K. A., and M. R. Stokes. 1986. Eating and resting salivation in early lactation dairy cows. J. Dairy Sci. 69:1282-1292.

Cheng, K. J., and R. J. Wallace. 1979. The mechanism of passage of endogenous urea through the rumen wall and the role of ureolytic epithelial bacteria in the urea flux. Br. J. Nutr. 42:553-557.

Cistola, D. P., D. M. Small, and J. A. Hamilton. 1982. Ionization behaviour of aqueous short-chain carboxylic acids: A carbon-13 NMR study. J. Lipid Res. 23:795-799.

Coats, D. A., and R. D. Wright. 1957. Secretion by the parotid gland of the sheep: The relationship between salivary flow and composition. J. Physiol. 135:611-622.

Colucci, P. E., G. K. MacLeod, W. L. Grovum, I. McMillan, and D. J. Barney. 1990. Digesta kinetics in sheep and cattle fed diets with different forage to concentrate ratios at high and low intakes. J. Dairy Sci. 73:2143-2156.

Counotte, G. H., A. T. van't Klooster, J. van der Kuilen, and R. A. Prins. 1979. An analysis of the buffer system in the rumen of dairy cattle. J. Anim. Sci. 49:1536-1544.

Dado, R. G., and M. S. Allen. 1993. Continuous computer acquisition of feed and water intakes, chewing, reticular motility, and ruminal pH of cattle. J. Dairy Sci. 76:1589-1600.

Danielli, J. F., M. W. S. Hitchcock, R. A. Marshall, and A. T. Phillipson. 1945. The mechanism of absorption from the rumen as exemplified by the behavior of acetic, propionic, and butyric acids. J. Exp. Biol. 22:75-84.

DeFrain, J. M., J. E. Shirley, E. C. Titgemeyer, A. F. Park, and R. T. Ethington. 2002. Impact of feeding a raw soybean hullcondensed corn steep liquor pellet on induced subacute ruminal acidosis in lactating cows. J. Dairy Sci. 85:2000-2008.

Delgado-Elorduy, A., C. B. Theurer, J. T. Huber, A. Alio, O. Lozano, M. Sadik, P. Cuneot, H. D. De Young, I. J. Simas, J. E. Santos, L. Nussio, C. Nussio, K. E. Webb Jr., and H. Tagari. 2002. Splanchnic and mammary nitrogen metabolism by dairy cows fed steam-rolled or steam-flaked corn. J. Dairy Sci. $85: 160-168$

Dijkstra, J., H. Boer, J. van Bruchem, M. Bruining, and S. Tamminga. 1993. Absorption of volatile fatty acids from the rumen of lactating dairy cows as influenced by volatile fatty acid concentration, $\mathrm{pH}$, and rumen liquid volume. Br. J. Nutr. 69:385-396.
Dirksen, G. 1970. Acidosis. Page 612 in Physiology of Digestion and Metabolism in the Ruminant. A. T. Phillipson, ed. Oriel Press, Newcastle upon Tyne, UK.

Dirksen, G. 1985. Der Pansenazidose-Komplex-Neuere Erkenntnisse und Erfahrungen (1). Eine Übersicht. Tierarztl. Prax. 13:501-512.

Dohme, F., T. J. DeVries, and K. A. Beauchemin. 2008. Repeated ruminal acidosis challenges in lactating dairy cows at high and low risk for developing acidosis: Ruminal pH. J. Dairy Sci. 91:3554-3567.

Duffield, T., K. C. Plaizier, A. Fairfield, R. Bagg, G. Vessie, P. Dick, J. Wilson, J. Aramini, and B. McBride. 2004. Comparison of techniques for measurement of rumen $\mathrm{pH}$ in lactating dairy cows. J. Dairy Sci. 87:59-66.

Edrise, B. M., and R. H. Smith. 1977. Absorption of volatile fatty acids in different compartments of the ruminant stomach. Proc. Nutr. Soc. 36:149. (Abstr.)

Emery, R. S., C. K. Smith, R. M. Grimes, C. F. Huffman, and C. W. Duncan. 1960. Physical and chemical changes in bovine saliva and rumen liquid with different hay-grain. J. Dairy Sci. 43:76-80.

Erdman, R. A. 1988. Dietary buffering requirements of the lactating dairy cow. J. Dairy Sci. 71:3246-3266.

Etschmann, B., K. S. Heipertz, A. von der Schulenburg, and M. Schweigel. 2006. A vH ${ }^{+}$-ATPase is present in cultured sheep ruminal epithelial cells. Am. J. Physiol. Gastrointest. Liver Physiol. 291:G1171-G1179.

Ferreira, H. G., F. A. Harrison, R. D. Keynes, and L. Zurich. 1972. Ion transport across an isolated preparation of sheep rumen epithelium. J. Physiol. 222:77-93.

Gäbel, G., and J. R. Aschenbach. 2006. Ruminal SCFA absorption: Channelling acids without harm. Page 173 in Ruminant Physiology: Digestion, Metabolism and Impact of Nutrition on Gene Expression, Immunology and Stress. K. Sejrsen, T. Hvelplund, and M. O. Nielsen, ed. Wageningen Academic Publishers, Wageningen, the Netherlands.

Gäbel, G., and J. R. Aschenbach. 2007. SCFA, protons and ruminal epithelium: The good, the bad, the barrier. Page 291 in Production Diseases in Farm Animals. M. Fürll, ed. Universität Leipzig, Leipzig, Germany.

Gäbel, G., J. R. Aschenbach, and F. Müller. 2002. Transfer of energy substrates across the ruminal epithelium: Implications and limitations. Anim. Health Res. Rev. 3:15-30.

Gäbel, G., M. Bestmann, and H. Martens. 1991a. Influences of diet, short-chain fatty acids, lactate and chloride on bicarbonate movement across the reticulorumen wall of sheep. Zentralbl. Veterinarmed. A 38:523-529.

Gäbel, G., F. Müller, H. Pfannkuche, and J. R. Aschenbach. 2001. Influence of isoform and DNP on butyrate transport across the sheep ruminal epithelium. J. Comp. Physiol. B 171:215-221.

Gäbel, G., S. Vogler, and H. Martens. 1991b. Short-chain fatty acids and $\mathrm{CO}_{2}$ as regulators of $\mathrm{Na}^{+}$and $\mathrm{Cl}^{-}$absorption in isolated sheep rumen mucosa. J. Comp. Physiol. B 161:419-426.

Gaebel, G., and H. Martens. 1988. Reversibility of acid induced changes in absorptive function of sheep rumen. Zentralbl. Veterinarmed. A 35:157-160.

Gaebel, G., H. Martens, M. Suendermann, and P. Galfi. 1987. The effect of diet, intraruminal $\mathrm{pH}$ and osmolarity on sodium, chloride and magnesium absorption from the temporarily isolated and washed reticulo-rumen of sheep. Q. J. Exp. Physiol. 72:501-511

Gärtner, K., P. Decker, and H. Hill. 1961. Untersuchungen über die Passage von Harnstoff und Ammoniak durch die Pansenwand von Ziegen. Pflugers Arch. 274:281-288.

Gärtner, K., and W. von Engelhardt. 1964. Untersuchungen über den Resorptionsmechanismus von Ammoniak an der Pansenschleimhaut. Dtsch. Tierarztl. Wochenschr. 71:57-60.

Gill, H. S., Q. Shu, and R. A. Leng. 2000. Immunization with Streptococcus bovis protects against lactic acidosis in sheep. Vaccine 18:2541-2548. 
Gozho, G. N., M. R. Hobin, and T. Mutsvangwa. 2008. Interactions between barley grain processing and source of supplemental dietary fat on nitrogen metabolism and urea-nitrogen recycling in dairy cows. J. Dairy Sci. 91:247-259.

Gozho, G. N., J. C. Plaizier, D. O. Krause, A. D. Kennedy, and K. M. Wittenberg. 2005. Subacute ruminal acidosis induces ruminal lipopolysaccharide endotoxin release and triggers an inflammatory response. J. Dairy Sci. 88:1399-1403.

Graf, C. M., M. Kreuzer, and F. Dohme. 2005. Effects of supplemental hay and corn silage versus full-time grazing on ruminal $\mathrm{pH}$ and chewing activity of dairy cows. J. Dairy Sci. 88:711-725.

Graham, C., I. Gatherar, I. Haslam, M. Glanville, and N. L. Simmons. 2007. Expression and localization of monocarboxylate transporters and sodium/proton exchangers in bovine rumen epithelium. Am. J. Physiol. Regul. Integr. Comp. Physiol. 292:R997-R1007.

Gray, F. V. 1947. The absorption of volatile fatty acids from the rumen. J. Exp. Biol. 24:1-14.

Gray, F. V. 1948. The absorption of volatile fatty acids from the rumen: II. The influence of $\mathrm{pH}$ on absorption. J. Exp. Biol. 25:135-144.

Gruby, D., and O. Delafond. 1843. Recherches sur des animalcules se développant en grand hombre dans l'estomac et dans les intestines pendant la digestion des animaux herbivores et carnivores. Compt. Rend. 17:1304-1308.

Hall, H. K. Jr. 1957. Correlation of the base strengths of amines. J. Am. Chem. Soc. 79:5441-5444.

Harmeyer, J., and H. Martens. 1980. Aspects of urea metabolism in ruminants with reference to the goat. J. Dairy Sci. 63:17071728.

Hird, F. J., R. B. Jackson, and M. J. Weidemann. 1966. Transport and metabolism of fatty acids by isolated rumen epithelium. Biochem. J. 98:394-400.

Hird, F. J., and M. J. Weidemann. 1964. Transport and metabolism of butyrate by isolated rumen epithelium. Biochem. J. 92:585-589.

Huhn, K., F. Müller, K. U. Honscha, H. Pfannkuche, and G. Gäbel. 2003. Molecular and functional evidence for a $\mathrm{Na}^{+}-\mathrm{HCO}_{3}{ }^{-}$ cotransporter in sheep ruminal epithelium. J. Comp. Physiol. B 173:277-284.

Hungate, R. E., R. W. Dougherty, M. P. Bryant, and R. M. Cello. 1952. Microbiological and physiological changes associated with acute indigestion in sheep. Cornell Vet. 42:423-449.

Kay, R. N. 1960. The rate of flow and composition of various salivary secretions in sheep and calves. J. Physiol. 150:515-537.

Kennedy, P., and L. Milligan. 1980. The degradation and utilization of endogenous urea in the gastrointestinal tract of ruminants: A review. Can. J. Anim. Sci. 60:205-221.

Khafipour, E., D. O. Krause, and J. C. Plaizier. 2009. Alfalfa pelletinduced subacute ruminal acidosis in dairy cows increases bacterial endotoxin in the rumen without causing inflammation. J. Dairy Sci. 92:1712-1724.

Kirat, D., J. Masuoka, H. Hayashi, H. Iwano, H. Yokota, H. Taniyama, and S. Kato. 2006. Monocarboxylate transporter 1 (MCT1) plays a direct role in short-chain fatty acids absorption in caprine rumen. J. Physiol. 576:635-647.

Kirat, D., Y. Matsuda, N. Yamashiki, H. Hayashi, and S. Kato. 2007. Expression, cellular localization and functional role of monocarboxylate transporter 4 (MCT4) in gastrointestinal tract of ruminants. Gene 391:140-149.

Kleen, J. L., G. A. Hooijer, J. Rehage, and J. P. Noordhuizen. 2003. Subacute ruminal acidosis (SARA): A review. J. Vet. Med. A Physiol. Pathol. Clin. Med. 50:406-414.

Kohn, R. A., and T. F. Dunlap. 1998. Calculation of the buffering capacity of bicarbonate in the rumen and in vitro. J. Anim. Sci. 76:1702-1709.

Koho, N., V. Maijala, H. Norberg, M. Nieminen, and A. R. Pösö. 2005. Expression of MCT1, MCT2 and MCT4 in the rumen, small intestine and liver of reindeer (Rangifer tarandus tarandus L.). Comp. Biochem. Physiol. A Mol. Integr. Physiol. 141:2934 .
Kolver, E. S., and M. J. de Veth. 2002. Prediction of ruminal pH from pasture-based diets. J. Dairy Sci. 85:1255-1266.

Krajcarski-Hunt, H., J. C. Plaizier, J.-P. Walton, R. Spratt, and B. W. McBride. 2002. Short communication: Effect of subacute ruminal acidosis on in situ fiber digestion in lactating dairy cows. J. Dairy Sci. 85:570-573.

Kramer, T., T. Michelberger, H. Gürtler, and G. Gäbel. 1996. Absorption of short chain fatty acids across ruminal epithelium of sheep. J. Comp. Physiol. B 166:262-269.

Krause, K. M., and D. K. Combs. 2003. Effects of forage particle size, forage source, and grain fermentability on performance and ruminal pH in midlactation cows. J. Dairy Sci. 86:13821397.

Krause, M. K., and G. R. Oetzel. 2006. Understanding and preventing subacute ruminal acidosis in dairy herds: A review. Anim. Feed Sci. Technol. 126:215-236.

Kristensen, N. B. 2001. Rumen microbial sequestration of [2-(13)C] acetate in cattle. J. Anim. Sci. 79:2491-2498.

Kristensen, N. B. 2005. Splanchnic metabolism of volatile fatty acids in the dairy cow. Anim. Sci. 80:3-10.

Kristensen, N. B., A. Danfaer, and N. Agergaard. 1996. Diurnal patterns of ruminal concentrations and portal appearance of short-chain fatty acids in sheep fed a hay or a concentrate straw diet in two meals daily. Acta Agric. Scand. A Anim. Sci. $46: 227-238$.

Kristensen, N. B., G. Gäbel, S. G. Pierzynowski, and A. Danfaer. 2000. Portal recovery of short-chain fatty acids infused into the temporarily-isolated and washed reticulorumen of sheep. Br. J. Nutr. 84:477-482.

Kristensen, N. B., and D. L. Harmon. 2004. Splanchnic metabolism of volatile fatty acids absorbed from the washed reticulorumen of steers. J. Anim. Sci. 82:2033-2042.

Kristensen, N. B., and D. L. Harmon. 2005. Effects of adding valerate, caproate, and heptanoate to ruminal buffers on splanchnic metabolism in steers under washed-rumen conditions. J. Anim. Sci. 83:1899-1907.

Lane, M. A., R. L. Baldwin 4th, and B. W. Jesse. 2002. Developmental changes in ketogenic enzyme gene expression during sheep rumen development. J. Anim. Sci. 80:1538-1544.

Laporte-Uribe, J., F. Brooks, M. Steer, P. Fernley, and M. Eivers. 2010. The application of reliable wireless sensor provides better understanding of the rumen environment. J. Anim. Sci. 88(ESuppl. 2):842. (Abstr.)

Lechartier, C., and J. L. Peyraud. 2010. The effects of forage proportion and rapidly degradable dry matter from concentrate on ruminal digestion in dairy cows fed corn silage-based diets with fixed neutral detergent fiber and starch contents. J. Dairy Sci. 93:666-681.

Leonhard-Marek, S., G. Breves, and R. Busche. 2006. Effect of chloride on $\mathrm{pH}$ microclimate and electrogenic $\mathrm{Na}^{+}$absorption across the rumen epithelium of goat and sheep. Am. J. Physiol. Gastrointest. Liver Physiol. 291:G246-G252.

Leonhard-Marek, S., and H. Martens. 1996. Effects of potassium on magnesium transport across rumen epithelium. Am. J. Physiol. 271:G1034-G1038.

Lettat, A., P. Nozière, M. Silberberg, D. P. Morgavi, C. Berger, and C. Martin. 2010. Experimental feed-induction of ruminal lactic, propionic, or butyric acidosis in sheep. J. Anim. Sci. 88:3041-3046.

Loncke, C., I. Ortigues-Marty, J. Vernet, H. Lapierre, D. Sauvant, and P. Nozièr. 2009. Empirical prediction of net portal appearance of volatile fatty acids, glucose, and their secondary metabolites ( $\beta$-hydroxybutyrate, lactate) from dietary characteristics in ruminants: A meta-analysis approach. J. Anim. Sci. $87: 253-268$

López, S., F. D. Hovell, J. Dijkstra, and J. France. 2003. Effects of volatile fatty acid supply on their absorption and on water kinetics in the rumen of sheep sustained by intragastric infusions. J. Anim. Sci. 81:2609-2616

Loste, A., J. J. Ramos, L. García, L. M. Ferrer, and M. T. Verde. 2005. High prevalence of ulcerative posthitis in Rasa Aragonesa 
rams associated with a legume-rich diet. J. Vet. Med. A Physiol. Pathol. Clin. Med. 52:176-179.

Mackie, R. I., and F. M. Gilchrist. 1979. Changes in lactate-producing and lactate-utilizing bacteria in relation to $\mathrm{pH}$ in the rumen of sheep during stepwise adaptation to a high-concentrate diet. Appl. Environ. Microbiol. 38:422-430.

Maekawa, M., K. A. Beauchemin, and D. A. Christensen. 2002. Effect of concentrate level and feeding management on chewing activities, saliva production, and ruminal $\mathrm{pH}$ of lactating dairy cows. J. Dairy Sci. 85:1165-1175.

Marini, J. C., J. D. Klein, J. M. Sands, and M. E. Van Amburgh. 2004. Effect of nitrogen intake on nitrogen recycling and urea transporter abundance in lambs. J. Anim. Sci. 82:1157-1164.

Marini, J. C., and M. E. Van Amburgh. 2003. Nitrogen metabolism and recycling in Holstein heifers. J. Anim. Sci. 81:545-552.

Markoff, J. 1913. Fortgesetzte Untersuchungen über die Gärungsprozesse bei der Verdauung der Wiederkäuer und des Schweines. Biochem. Z. 57:1-49.

Martin, C., N. B. Kristensen, and P. Huhtanen. 2001. Comparison of non-tracer and tracer methods for determination of volatile fatty acid production rate in the rumen of sheep fed on two levels of intake. Br. J. Nutr. 86:331-340.

Masson, M. J., and A. T. Phillipson. 1951. The absorption of acetate, propionate and butyrate from the rumen of sheep. J. Physiol. 113:189-206.

McDonald, I. W. 1948. The absorption of ammonia from the rumen of the sheep. Biochem. J. 42:584-587.

McDougall, E. I. 1948. Studies on ruminant saliva. 1. The composition and output of sheep's saliva. Biochem. J. 43:99-109.

McLaughlin, C. L., A. Thompson, K. Greenwood, J. Sherington, and C. Bruce. 2009. Effect of acarbose on acute acidosis. J. Dairy Sci. 92:2758-2766.

Morgante, M., C. Stelletta, P. Berzaghi, M. Gianesella, and I. Andrighetto. 2007. Subacute rumen acidosis in lactating cows: An investigation in intensive Italian dairy herds. J. Anim. Physiol. Anim. Nutr. (Berl.) 91:226-234.

Mouriño, F., R. Akkarawongsa, and P. J. Weimer. 2001. Initial pH as a determinant of cellulose digestion rate by mixed ruminal microorganisms in vitro. J. Dairy Sci. 84:848-859.

Müller, F., J. R. Aschenbach, and G. Gäbel. 2000. Role of $\mathrm{Na}^{+} / \mathrm{H}^{+}$ exchange and $\mathrm{HCO}_{3}{ }^{-}$transport in $\mathrm{pH}_{\mathrm{i}}$ recovery from intracellular acid load in cultured epithelial cells of sheep rumen. J. Comp. Physiol. B 170:337-343.

Müller, F., K. Huber, H. Pfannkuche, J. R. Aschenbach, G. Breves, and G. Gäbel. 2002. Transport of ketone bodies and lactate in the sheep ruminal epithelium by monocarboxylate transporter 1 . Am. J. Physiol. Gastrointest. Liver Physiol. 283:G1139-G1146.

Muscher, A. S., B. Schröder, G. Breves, and K. Huber. 2010. Dietary nitrogen reduction enhances urea transport across goat rumen epithelium. J. Anim. Sci. 88:3390-3398.

Nocek, J. E. 1997. Bovine acidosis: Implications on laminitis. J. Dairy Sci. 80:1005-1028.

Nordlund, K. V., and E. F. Garrett. 1994. Rumenocentesis: A technique for the diagnosis of subacute rumen acidosis in dairy herds. Bovine Pract. 28:109-112.

Norton, B. W., J. B. Mackintosh, and D. G. Armstrong. 1982. Urea synthesis and degradation in sheep given pelleted-grass diets containing flaked barley. Br. J. Nutr. 48:249-264.

Oba, M., and M. S. Allen. 2003a. Effects of corn grain conservation method on feeding behavior and productivity of lactating dairy cows at two dietary starch concentrations. J. Dairy Sci. $86: 174-183$.

Oba, M., and M. S. Allen. 2003b. Effects of diet fermentability on efficiency of microbial nitrogen production in lactating dairy cows. J. Dairy Sci. 86:195-207.

Obara, Y., D. Dellow, and J. Nolan. 1991. Effects of energy-rich supplements on nitrogen kinetics in ruminants. Page 551 in Physiological Aspects of Digestion and Metabolism in Ruminants. T. Tsuda, Y. Sasaki, and R. Kawashima, ed. Academic Press, San Diego, CA.
Owens, F. N., D. S. Secrist, W. J. Hill, and D. R. Gill. 1998. Acidosis in cattle: A review. J. Anim. Sci. 76:275-286.

Parker, D. S., M. A. Lomax, C. J. Seal, and J. C. Wilton. 1995. Metabolic implications of ammonia production in the ruminant. Proc. Nutr. Soc. 54:549-563.

Penner, G. B., J. R. Aschenbach, G. Gäbel, and M. Oba. 2009a. Epithelial capacity for the apical uptake of short-chain fatty acids is a key determinant for intra-ruminal $\mathrm{pH}$ and the susceptibility to sub-acute ruminal acidosis in sheep. J. Nutr. 139:1714-1720.

Penner, G. B., J. R. Aschenbach, G. Gäbel, and M. Oba. 2009b. Technical note: Evaluation of a continuous ruminal $\mathrm{pH}$ measurement system for use in non-cannulated small ruminants. J. Anim. Sci. 97:2363-2366.

Penner, G. B., and K. A. Beauchemin. 2010. Variation among cows in their susceptibility to acidosis: Challenge or opportunity? Adv. Dairy Technol. 22:173-187.

Penner, G. B., K. A. Beauchemin, and T. Mutsvangwa. 2006. An evaluation of the accuracy and precision of a stand-alone submersible continuous ruminal $\mathrm{pH}$ measurement system. J. Dairy Sci. 89:2132-2140.

Penner, G. B., K. A. Beauchemin, and T. Mutsvangwa. 2007. The severity of ruminal acidosis in primiparous Holstein cows during the periparturient period. J. Dairy Sci. 90:365-375.

Penner, G. B., and M. Oba. 2009. Increasing dietary sugar concentration may improve dry matter intake, ruminal fermentation, and productivity of dairy cows in the post-partum phase of the transition period. J. Dairy Sci. 92:3341-3353.

Penner, G. B., M. Taniguchi, L. L. Guan, K. A. Beauchemin, and M. Oba. 2009c. The dietary forage to concentrate ratio does not affect the rate of volatile fatty acid absorption but alters the expression of genes regulating energy metabolism in rumen tissue. J. Dairy Sci. 92:2767-2781.

Pennington, R. J. 1951. Metabolism of lower fatty acids by sheep rumen epithelium. Biochem. J. 49:lix. (Abstr.)

Peters, J. P., R. Y. Shen, J. A. Robinson, and S. T. Chester. 1990. Disappearance and passage of propionic acid from the rumen of the beef steer. J. Anim. Sci. 68:3337-3349.

Phillipson, A. T., and R. A. McAnally. 1942. Studies on the fate of carbohydrates in the rumen of the sheep. J. Exp. Biol. 19:199214.

Pilgrim, A. F., F. V. Gray, and G. B. Belling. 1969. Production and absorption of ammonia in the sheep's stomach. Br. J. Nutr. 23:647-655

Pitt, R. E., J. S. Van Kessel, D. G. Fox, A. N. Pell, M. C. Barry, and P. J. Van Soest. 1996. Prediction of ruminal volatile fatty acids and $\mathrm{pH}$ with the net carbohydrate and protein system. J. Anim. Sci. 74:226-244.

Plaizier, J. C., D. O. Krause, G. N. Gozho, and B. W. McBride. 2008. Subacute ruminal acidosis in dairy cows: The physiological causes, incidence and consequences. Vet. J. 176:21-31.

Reis, R. B., and D. K. Combs. 2000. Effects of corn processing and supplemental hay on rumen environment and lactation performance of dairy cows grazing grass-legume pasture. J. Dairy Sci. 83:2529-2538.

Rémond, D., J. P. Chaise, E. Delval, and C. Poncet. 1993. Net transfer of urea and ammonia across the ruminal wall of sheep. J. Anim. Sci. 71:2785-2792.

Resende Júnior, J. C., M. N. Pereira, H. Bôer, and S. Tamminga. 2006. Comparison of techniques to determine the clearance of ruminal volatile fatty acids. J. Dairy Sci. 89:3096-3106.

Reynolds, C. K., and N. B. Kristensen. 2008. Nitrogen recycling through the gut and the nitrogen economy of ruminants: An asynchronous symbiosis. J. Anim. Sci. 86(E. Suppl.):E293E305.

Ritzhaupt, A., I. Wood, A. Jackson, B. Moran, and S. ShiraziBeechey. 1998. Isolation of a RT-PCR fragment from human colon and sheep rumen RNA with nucleotide sequence similarity to human and rat urea transporter isoforms. Biochem. Soc. Trans. 26:S122. (Abstr.) 
Russell, J. B., and F. Diez-Gonzalez. 1998. The effects of fermentation acids on bacterial growth. Adv. Microb. Physiol. 39:205234.

Russell, J. B., and J. L. Rychlik. 2001. Factors that alter rumen microbial ecology. Science 292:1119-1122.

Russell, J. B., and D. B. Wilson. 1996. Why are ruminal cellulolytic bacteria unable to digest cellulose at low pH? J. Dairy Sci. 79:1503-1509.

Scheunert, A., and A. Trautmann. 1921. Studies on saliva secretion. II. The parotid and submaxillary secretion of the sheep. Pflüg. Arch. 192:30-33.

Sederevicius, A., and J. Kantautaité. 1993. Different forms of rumen dystonia in dairy cows. Acta Vet. Scand. Suppl. 89:119-124.

Segel, I. H. 1976. Biochemical Calculations. 2nd ed. John Wiley \& Sons, New York, NY.

Sehested, J., L. Diernaes, P. D. Møller, and E. Skadhauge. 1996. Transport of sodium across the isolated bovine rumen epithelium: Interaction with short-chain fatty acids, chloride and bicarbonate. Exp. Physiol. 81:79-94.

Sehested, J., L. Diernaes, P. D. Møller, and E. Skadhauge. 1999. Transport of butyrate across the isolated bovine rumen epithelium-Interaction with sodium, chloride and bicarbonate. Comp. Biochem. Physiol. A Mol. Integr. Physiol. 123:399408.

Siddons, R. C., J. V. Nolan, D. E. Beever, and J. C. Macrae. 1985. Nitrogen digestion and metabolism in sheep consuming diets containing contrasting forms and levels of N. Br. J. Nutr. 54:175-187.

Steele, M. A., O. AlZahal, S. E. Hook, J. Croom, and B. W. McBride. 2009. Ruminal acidosis and the rapid onset of ruminal parakeratosis in a mature dairy cow: A case report. Acta Vet. Scand. $51: 39$.

Stevens, C. E., and B. K. Stettler. 1966a. Factors affecting the transport of volatile fatty acids across rumen epithelium. Am. J. Physiol. 210:365-372.

Stevens, C. E., and B. K. Stettler. 1966b. Transport of fatty acid mixtures across rumen epithelium. Am. J. Physiol. 211:264271.

Stevens, C. E., and B. K. Stettler. 1967. Evidence for active transport of acetate across bovine rumen epithelium. Am. J. Physiol. 213:1335-1339.

Stone, W. C. 2004. Nutritional approaches to minimize subacute ruminal acidosis and laminitis in dairy cattle. J. Dairy Sci. 87(E. Suppl.):E13-E26.

Storm, A. C., and N. B. Kristensen. 2010. Effects of particle size and dry matter content of a total mixed ration on intraruminal equilibration and net portal flux of volatile fatty acids in lactating dairy cows. J. Dairy Sci. 93:4223-4238.

Stumpff, F., H. Martens, S. Bilk, J. R. Aschenbach, and G. Gäbel. 2009. Cultured ruminal epithelial cells express a large-conductance channel permeable to chloride, bicarbonate, and acetate. Pflugers Arch. 457:1003-1022.
Sutton, J. D., M. S. Dhanoa, S. V. Morant, J. France, D. J. Napper, and E. Schuller. 2003. Rates of production of acetate, propionate, and butyrate in the rumen of lactating dairy cows given normal and low-roughage diets. J. Dairy Sci. 86:3620-3633.

Tamminga, S., and A. M. van Vuuren. 1988. Formation and utilization of end products of lignocellulose degradation in ruminants. Anim. Feed Sci. Technol. 21:141-159.

Thorlacius, S. O., A. Dobson, and A. F. Sellers. 1971. Effect of carbon dioxide on urea diffusion through bovine ruminal epithelium. Am. J. Physiol. 220:162-170.

Tiedemann, F., and L. Gmelin. 1826. Die Verdauung nach Versuchen. Bd. 1. Gross, Heidelberg und Leipzig, Germany.

Turner, A. W., and V. E. Hodgetts. 1955. Buffer systems in the rumen of the sheep. II. Buffering properties in relationship to composition. Aust. J. Agric. Res. 6:125-144.

Udén, P. 2010. Using a novel macro in vitro technique to estimate differences in absorption rates of volatile fatty acids in the rumen. J. Anim. Physiol. Anim. Nutr. (Berl.) doi:10.1111/j.14390396.2009.00976.x

Uhart, B. A., and F. D. Carroll. 1967. Acidosis in beef steers. J. Anim. Sci. 26:1195-1198.

Underwood, W. J. 1992. Rumen lactic acidosis: Part 1. Epidemiology and pathophysiology. Compend. Contin. Educ. Pract. Vet. 14:1127-1133.

von Engelhardt, W., and R. Hauffe. 1975. Role of the omasum in absorption and secretion of water and electrolytes in sheep and goats. Page 216 in Digestion and Metabolism in the Ruminant. I. W. McDonald and A. C. I. Warner, ed. Univ. New England Publ. Unit, Armidale, New South Wales, Australia.

Walter, A., and J. Gutknecht. 1986. Permeability of small nonelectrolytes through lipid bilayer membranes. J. Membr. Biol. 90:207-217.

Wang, J., and D. Y. Fung. 1996. Alkaline-fermented foods: A review with emphasis on pidan fermentation. Crit. Rev. Microbiol. 22:101-138.

Williams, V. J., and D. D. Mackenzie. 1965. The absorption of lactic acid from the reticulo-rumen of the sheep. Aust. J. Biol. Sci. 18:917-934.

Zebeli, Q., J. Dijkstra, M. Tafaj, H. Steingass, B. N. Ametaj, and W. Drochner. 2008a. Modeling the adequacy of dietary fiber in dairy cows based on the responses of ruminal $\mathrm{pH}$ and milk fat production to composition of the diet. J. Dairy Sci. 91:20462066.

Zebeli, Q., M. Tafaj, I. Weber, H. Steingass, and W. Drochner. 2008b. Effects of dietary forage particle size and concentrate level on fermentation profile, in vitro degradation characteristics and concentration of liquid- or solid-associated bacterial mass in the rumen of dairy cows. Anim. Feed Sci. Technol. 140:307-325.

Zuntz, N. 1879. Gesichtspunkte zum kritischen Studium der neueren Arbeiten auf dem Gebiete der Ernährung. Landwirtschaft. Jahrbuch 8:65-117. 
References

Citations
This article cites 156 articles, 50 of which you can access for free at: http://www.journalofanimalscience.org/content/89/4/1092\#BIBL

This article has been cited by 2 HighWire-hosted articles:

http://www.journalofanimalscience.org/content/89/4/1092\#otherarticles 